\title{
EXPOSIÇÃO DE CORPOS HUMANOS: O USO DE CADÁVERES COMO ENTRETENIMENTO E MERCADORIA
}

\author{
Joon Ho Kim
}

\section{O cadáver espetáculo}

Em 2007, o Brasil recebeu a exposição de anatomia intitulada Bodies revealed: Fascinating + real, traduzida como Corpo humano: Real e fascinante. Cerca de 670 mil pessoas (Abas 2010) de diversas cidades brasileiras puderam visitar a exposição na qual os objetos expostos eram nada menos do que 16 cadáveres e 225 órgãos humanos (Corpo Humano 2007). Adentrar em um salão repleto de cadáveres estripados e mutilados deveria suscitar a mesma sensação de uma câmara dos horrores, já que os mortos são notoriamente objetos de tabu, fontes de mana, considerados impuros, perigosos e, não raramente, repugnantes. Entretanto, os corpos dissecados da exposição, apresentados esfolados ou fatiados, inteiros ou em partes, eviscerados ou não, e tematicamente organizados em sistemas - esquelético, muscular, nervoso, respiratório, digestório, excretor, reprodutor, circulatório - eram tratados como objetos de "arte". Ao contrário daqueles grandes vidros de formol que distorcem a imagem do seu conteúdo desbotado, largamente usados em laboratórios e museus para conservar restos biológicos, Bodies Revealed é um espetáculo cadavérico no qual corpos dissecados e partes corporais reduzidos a formas, cores e texturas - são espetacularmente exibidos em pedestais, displays e caixas transparentes, distribuídos meticulosamente em espaços organizados e iluminados para realçar suas formas e cores.

O cadáver da exposição que aparece na capa do catálogo (Geller 2007) e na seção intitulada "O Corpo Revelado" (Geller 2007:4-5) é uma espécie de síntese do espírito da exposição. É um corpo esculpido de acordo com a mesma lógica visual que encontramos nas máquinas exibidas em feiras e exposições tecnológicas, apresentadas em cortes esquemáticos ou na chamada "vista explodida", para expor suas partes internas com o objetivo de dar ao espectador a visão funcional dos subsistemas que compõem o todo. No cadáver-síntese da exposição, a preservação de anéis de pele e das partes 
externas marcantes, tais como nariz, umbigo, orelhas e mamilos, esquematiza a configuração da superfície corporal. Um dos olhos do morto permite a visualização dos músculos orbiculares, que não escondem o padrão caracteristicamente asiático, enquanto o outro olho, que exibe o encaixe do globo ocular com a órbita, parece esbugalhado. Em todo o corpo, vários músculos também foram seccionados junto com os anéis da pele para mostrar nervos, órgãos, artérias e ossos localizados nas camadas mais internas. Dessa forma, os pulmões são visíveis dentro da gaiola de costelas que forma a caixa toráxica e, na região do abdômen, é o sistema excretor, do rim à bexiga, que está exposto em um ventre quase vazio de vísceras.

Esse cadáver, assim como todos os demais, é tecnicamente denominado de "espécime" e, apesar de ser evidentemente um corpo humano, parece feito de material plástico, seco e inodoro, características que resultam do processo utilizado na sua preservação. A técnica empregada, conhecida como plastinação [plastination] ou preservação por polímero [polymer preservation], é um processo que substitui a água e a gordura presentes no corpo por polímeros plásticos que acabam dando a ele um aspecto sintético característico. Conforme explica von Hagens (s/d), inventor da técnica, a plastinação de um cadáver requer que ele tenha o processo de putrefação interrompido o mais rápido possível para garantir a boa aparência do "espécime". Isto é feito embalsamando-se o corpo com uma solução de formol que é bombeada pelas artérias logo depois de sua morte. Na etapa seguinte, o cadáver é dissecado e mergulhado em uma banheira de acetona ou outro solvente capaz de dissolver a água e a gordura do corpo, os componentes que efetivamente alimentam o processo de putrefação. Após esta etapa, o cadáver é submetido a um processo a vácuo que promove a substituição da acetona por polímero líquido - tal como o silicone - que impregna os tecidos à medida que a acetona é convertida ao estado gasoso.

A duração desses processos de substituição química é proporcional ao tamanho do "espécime" a ser conservado e pode levar meses. Finalmente, após a saturação com polímeros, o espécime é "modelado" e fixado na posição que manterá definitivamente após a cura do plástico. O produto final é um cadáver ou parte cadavérica inodora que se assemelha, visualmente e ao toque, a um modelo plástico. Em certo sentido, os produtos da plastinação são cadáveres fossilizados que, ao invés de terem sido mineralizados naturalmente, foram plastificados sinteticamente.

Há um evidente sensacionalismo mórbido nas exposições de corpos humanos, visto que não haveria o mesmo apelo se os corpos expostos fossem sintéticos ou de animais. Isto evidencia o fato de que a relação que se estabelece entre nós, espectadores, e os cadáveres expostos tem uma dimensão 
social, distinta da que teríamos se fossem apenas modelos de plástico ou cera, ainda que reproduções perfeitas, ou de um cadáver animal, qualquer que seja a técnica de conservação. As exposições de corpos humanos até podem oferecer motivações mais nobres do que o simples entretenimento mórbido, mas sem abrirem mão da morbidez como peça fundamental do espetáculo. Com efeito, o tom geral daqueles que defendem essas exposições apela para a utilidade educativa de se usarem corpos humanos reais, dissecados e modelados, em posições didáticas, pois esta técnica possibilita o acesso a "espécimes" cuja riqueza de detalhes e de informações era antes acessível apenas aos anatomistas.

Os críticos dessas exposições, por outro lado, atacam a cadeia produtiva e comercial que se inicia na captação suspeita desses corpos e o elo final que efetivaria, sob uma fachada de empreendimento educativo, o consumo desses cadáveres na forma de espetáculo. De fato, quando um diorama com cadáveres plastinados jogando cartas é especificamente produzido para um filme - Cassino Royale, da série 007 - e a cantora Lady Gaga, conhecida por suas performances e cenários surreais, se interessa pelos cadáveres plastinados (Kiefer 2010), o que está em pauta é o entretenimento, não a educação. Entretanto, o uso de cadáveres como forma de entretenimento está longe de ser inédito.

Schwartz (2001:412-420) relata que o necrotério de Paris, na virada do século XIX para o século XX, não só era acessível ao público em geral, sob o pretexto de permitir a identificação de cadáveres encontrados em vias públicas, como era "celebrado como um teatro público" e "listado em praticamente todos os guias da cidade". Aberto sete dias por semana, chegava a ter até 40 mil visitantes nos dias de maior movimento, e um comércio de quitutes lotava a calçada do lado de fora. A autora cita o caso da exibição do cadáver da enfant de la rue du Vert-Bois, encontrado em 29 de julho de 1886, que foi colocado na salle d'exposition do necrotério, vestida e sentada em uma cadeira. Apesar da enorme visitação — os jornais teriam registrado até um grande tumulto em 5 de agosto, quando 150 mil pessoas tiveram que ser organizadas em grupos de 50 visitantes por vez — ninguém identificou o corpo. Uma autópsia foi realizada apenas em 6 de agosto, quando os médicos constataram que a menina havia se engasgado com uma minhoca e morrido sufocada.

De acordo com a autora, o necrotério seria um "auxiliar visual do jornal, colocando no palco os mortos que haviam sido descritos em detalhe, com sensacionalismo, pela palavra impressa" (Schwartz 2001:415). Esse sensacionalismo, para Singer (2001:127), está relacionado a um processo de compensação da atitude blasé (Simmel 1967), que é fundamentalmente 
o embotamento dos sentidos em face da exagerada exposição sensorial que aflige as pessoas nas metrópoles. A descrição meticulosamente escatológica dos corpos mortos ou mutilados seria uma forma de compensar esse tipo de atitude, pois tocariam, de acordo com Singer (2001:127), em uma "hiperconsciência especificamente histórica da vulnerabilidade física no ambiente moderno".

Apesar de público e gratuito, e talvez justamente por isso, o necrotério de Paris era muito popular e estava engendrado em um circuito no qual "a vida era vivenciada como um show, mas ao mesmo tempo os shows tornavam-se cada vez mais parecidos com a vida real" (Schwartz 2001:411). Nesse sentido, o necrotério era o local procurado pelas pessoas comuns para experienciarem a "realidade" dos fatos sensacionais noticiados nos periódicos. Não era a identificação dos cadáveres que levava milhares de pessoas ao necrotério, mas o voyeurismo motivado pela espetacularização da morte. O próprio administrador do necrotério teria dito que este "é muito mais fascinante do que até mesmo um museu de cera, porque as pessoas exibidas são realmente de carne e osso" (Schwartz 2001:420). Um cartum publicado por ocasião da inauguração do Musée Grévin demonstra como o necrotério era popularmente visto como lugar de entretenimento. Nele, "dois operários olham boquiabertos uma figura de cera estendida em uma laje. Um diz: 'Uau, parece um cadáver de verdade'. Seu amigo responde: 'Isso é quase tão divertido quanto o necrotério'" (Schwartz 2001:420). As visitações públicas ao necrotério de Paris foram encerradas em 1907, não sem protestos (Schwartz 2001:414).

Se a morte como processo social, a partir do fim do século XIX, foi sendo afastada do olhar público, mormente em decorrência do progressivo isolamento dos doentes e moribundos em hospitais e dos cadáveres em necrotérios, isso não significou que a oferta ou a demanda pelo mórbido tivesse diminuído. As mídias visuais que se popularizaram a partir daquele período continuaram a dar vazão ao mesmo sensacionalismo, fosse de forma explícita ou disfarçada. Cartões-postais com imagens de gente linchada (Allen 2000) serviram de souvenir e de meio de socialização de imagens mórbidas entre o final do século XIX e início do século XX. Atualmente, longe de ter se extinguido, compartilhar imagens de gente morrendo e de cadáveres estropiados tornou-se lugar comum na Internet, para onde convergiram fotos e vídeos, em sua maioria vernaculares, de acidentes, guerras, execuções, atentados e tudo mais relacionado com a morte.

Na indústria cultural, sempre que necessário, a importância da informação é invocada para disfarçar o sensacionalismo e atender ao voyeurismo mórbido com imagens reais. O filme Faces of death (1978) é uma redução ao 
absurdo dessa lógica, uma caricatura de documentário que compila cenas grotescas - tanto de mortes explícitas como de reencenações de qualidade péssima que fingem também ser reais - apresentadas por um ator que se passa por médico legista e que afirma ter como objetivo mostrar as diferentes "faces" da morte. O filme foi criticado e censurado em diversos países pela sua violência gratuita, mas resultou em sucesso financeiro, tendo arrecadado 35 milhões de dólares, apenas no cinema, contra um custo de produção estimado de 450 mil dólares (IMDb, s.d.), motivando várias continuações e versões.

Um exemplo mais recente do voyeurismo disfarçado é o fenômeno imagético do "11 de Setembro", fonte inesgotável de matérias televisivas e de documentários que sempre têm algo "inédito" na cadeia das mesmas imagens repetidas e repetidas à exaustão. Destaca-se dentre os documentários, 9/11: The falling man (2006) que, sob o pretexto de identificar a pessoa que aparece em uma imagem do fotógrafo Richard Drew, conhecida como The falling man, compila inúmeras cenas das pessoas saltando do World Trade Center em chamas que, apesar de abundantes, foram tratadas como tabu e pouco veiculadas na mídia na época do atentado (Cf. Cauchon \& Moore 2002).

Um aspecto que aproxima as exibições de corpos humanos plastinados dos museus de cera é que ambos usam o mesmo princípio de modelar os corpos em "situações" caracterizadas pela pose e a composição com adereços - uma bola de futebol ou de basquete, um arco e flecha - e mesmo dioramas, tais como cadáveres em uma mesa de carteado ou em um jogo de xadrez. A única diferença entre uma instalação com bonecos de cera e de outra com corpos plastinados é o fato de que a segunda faz uso de cadáveres. O espetáculo será tanto mais grandioso quanto mais surreal for a situação na qual o cadáver seja colocado. A primeira exposição itinerante com cadáveres plastinados, intitulada Body Worlds (figuras 1-3), estreou na cidade de Tóquio em 1995, e foi produzida pela empresa de mesmo nome, fundada pelo inventor desta técnica, o médico anatomista Gunther von Hagens. Sobre uma das edições da Body Worlds, Braslaukas (2001) comenta que:

O médico [von Hagens] usou imagens conhecidas como a "Vênus de Milo", de Salvador Dalí, para exibir os órgãos internos de um corpo masculino. Nele, veem-se rins, estômago, intestinos e outros órgãos, dispostos como gavetas que saem da barriga e do rosto do cadáver [figura 3].

Há também corpos sem pele e fatiados de diferentes formas, colocados como um atleta, uma nadadora, um corredor, um jogador de xadrez e até um cavaleiro montado em um cavalo de porte bastante grande e também aberto em várias partes. 
O cavaleiro e o cavalo descritos por Braslaukas são claramente uma releitura do trabalho de outro anatomista: Le cavalier et sa monture, de Honoré Fragonard (figura 4). Assim como von Hagens, Fragonard, dois séculos antes, se notabilizou por preservar corpos dissecados de animais e pessoas, posicionados como se estivessem vivos, através de técnicas que combinavam dissecação com desidratação, injeção de cera e resina, especialmente nos vasos sanguíneos, e aplicação de verniz (Simon 2002:70). No século XVIII, antes que a formalina passasse a ser usada largamente para evitar a putrefação de corpos humanos e animais, técnicas como as de Fragonard eram comuns e viabilizavam o uso de cadáveres como substitutos mais baratos do que os modelos artesanais em cera (Simon 2002:66-67). Corpos ou partes corporais conservadas e modelos de cera visavam suprir uma demanda que não era atendida pelas dissecações, já que estas eram limitadas às estações frias do ano e à oferta de cadáveres.

Apesar da aparência mumificada decorrente do processo usado por Fragonard, a modelagem e o posicionamento dados por ele aos corpos dissecados proporcionavam um ar desconcertantemente vívido: bustos com expressões ameaçadoras, um corpo inteiro em pé com o pênis rijo e fetos dançando. Em contraste com o trabalho de Fragonard, que têm seu aspecto cadavérico acentuado, as exibições contemporâneas de corpos humanos revestem o cadáver de uma aparência totalmente sintética e estéril e reproduzem nele a imagem do corpo-máquina inspirada nas ilustrações anatômicas. Tanto em um caso como no outro, é evidente que o corpo não é nada além de insumo, pois qual o significado de se colocarem cadáveres dissecados como se estivessem jogando bola, tocando guitarra, pulando, dançando ou mesmo copulando que não seja o de que o corpo humano pode e deve ser apropriado como mera matéria-prima para ser esculpida de acordo com os desejos estéticos de alguém? Como afirma von Hagens:

Acima de tudo, preparar a plastinação de um corpo inteiro é uma realização intelectual e escultural que requer que o plastinador tenha uma figura mental dos resultados antes mesmo de iniciar o projeto. Visto dessa perspectiva, a plastinação pode ser comparada ao trabalho de um artista que esculpe uma figura em um bloco de pedra ou que prepara o molde de barro para uma estátua de bronze (Institute for Plastination 2007:13, tradução minha).

Segundo Debord (2000:14), o espetáculo é uma relação social na qual a mediação entre pessoas é substituída pela mediação entre imagens. A relação que temos com os cadáveres nas exposições de corpos humanos é justamente aquela com as imagens consagradas pela anatomia das quais eles são o medium. O cadáver aqui é mero substrato recortado e modelado para 
Figura 1 - The kicker, corpo plastinado da Body Worlds

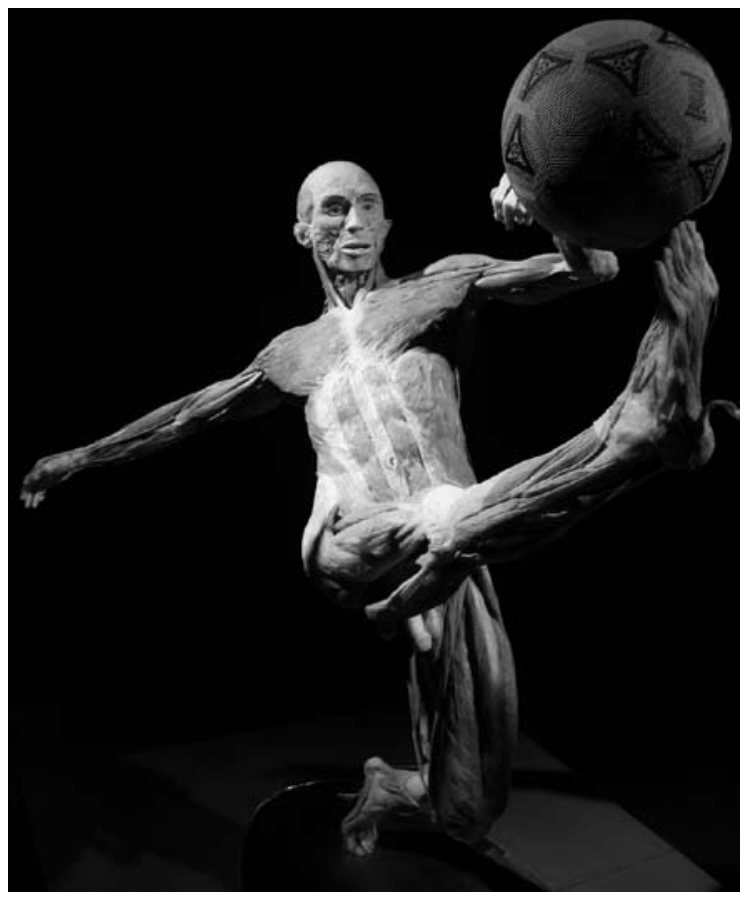

Fonte: LINDSEY, Mike. 2006 Alguns direitos reservados (CC BY-NC-ND 2.0)

reproduzir as ilustrações dos tratados clássicos. Sua função é dar presença a uma coisa que não é a pessoa que aquele corpo foi, mas representar uma das possíveis instâncias do artefato biomecânico tal qual descreve a ciência.

Além de recuperarem o realismo máximo do necrotério com as vantagens dos bonecos de cera, os corpos plastinados vão além da experiência do real ao materializar em carne e ossos plastificados uma imagem corporal hiper-real ou surreal que antes só era possível por meio da computação gráfica e da pintura. De acordo com Belting (2007:111), “a exposição 'Körperwelten' [...] evitou o conceito de imagem ao mostrar cadáveres reais, que na exposição satisfizeram a ânsia sensacionalista por imagens que são mais que imagens". Nas exposições de corpos humanos, a imagem do corpo anatomizado torna-se presente aos nossos sentidos em um processo circular, utilizando como matéria-prima o próprio cadáver, que é originalmente a fonte do saber anatômico. Sabemos que o cadáver é real, porém o que é enfatizado no espetáculo é aquilo para o qual ele foi remodelado para representar, pois o cadáver não está mais ali como a origem do saber anatômico, mas é simples matéria-prima — recortada, escavada, esculpida — 
Figura 2 - The skin man, corpo plastinado da Body Worlds

Figura 3 - Corpo plastinado da Body Worlds

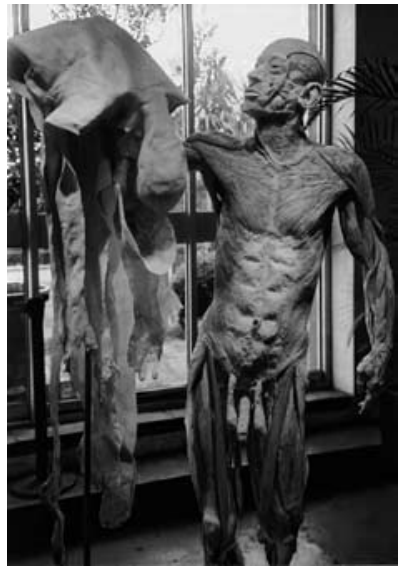

Fonte: Stevenson, Paul. 2004. Alguns direitos reservados (CC BY-NC-ND 2.0)

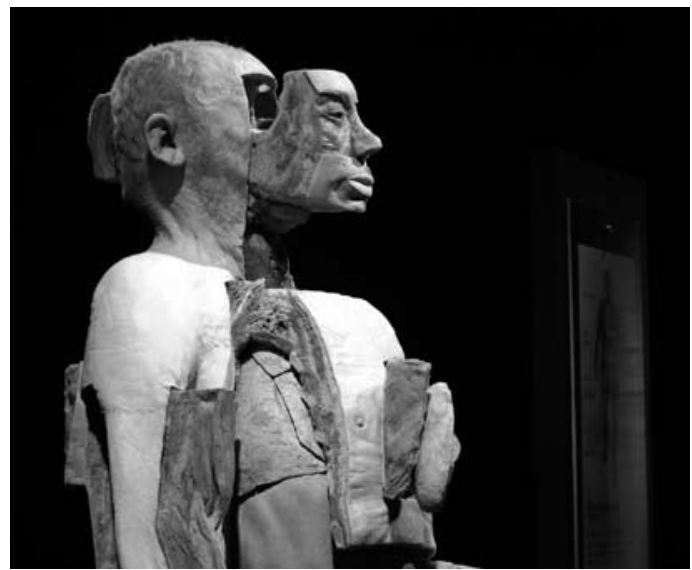

Fonte: Mooney, Paty. 2009. Alguns direitos reservados (CC BY-NC-ND 2.0)

da qual se remove o excesso para deixar apenas aquilo que corresponde ao corpo-máquina celebrado nos tratados anatômicos.

Um desses excessos é o conjunto de traços e evidências que ligam aquele cadáver a um indivíduo específico. O apagamento desses traços é fundamental para sustentar o apelo espetacular que representa no cadáver não a finitude da nossa existência, mas a mecânica do corpo vivo, em uma direção que é justamente contrária à do velório e do funeral. Daí a necessidade de fixar o cadáver em posições e situações hiper-reais ou surreais, como se estivessem vivos ou congelados no momento emblemático de alguma ação. Mais do que recursos que reforçam o espetacular, a representação hiper-real ou surreal constitui condição necessária para que a real dimensão cadavérica não arruíne o show.

\section{O corpo anatomizado}

Existe uma visível conexão entre as exposições de corpos plastinados e as dissecações que floresceram a partir da Renascença, pois elas reconstroem em carne e osso a imagem corporal consagrada por nomes da anatomia clássica (figuras 7-16), como Andreas Vesalius (1514-1564), considerado fundador 
Figura 4 - Montagem de corpos de cavaleiro e cavalo feita por Honoré Fragonard entre 1766 e 1771

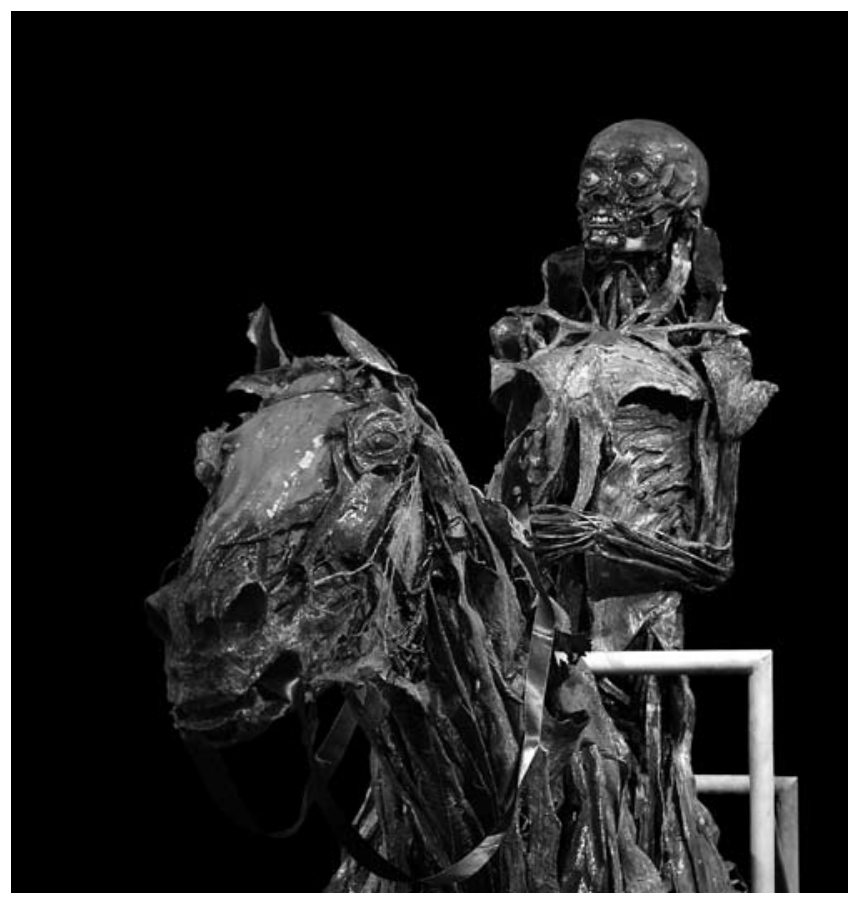

Fonte: Jebulon. 2011. Domínio público (CC0 1.0)

da anatomia moderna, Leonardo da Vinci (1452-1519), Siegfried Albinus (1697-1770), Valverde de Amusco (1525-1587?), Govert Bidloo (1649-1713), dentre outros. Von Hagens nunca escondeu sua grande inspiração: “Eu sou anatomista há mais de trinta e cinco anos e durante a minha carreira eu tenho dedicado enorme esforço para apresentar exibições dentro da tradição da anatomia renascentista" (Hamburg \& Gomez 2009; tradução minha). Uma das citações mais famosas de von Hagens (figura 2) é a reprodução literal em um cadáver real da ilustração de Valverde de Amusco em que um corpo esfolado segura sua própria pele (figura 13).

Belting (2007:110) argumenta que a imagem de uma pessoa pode ser contemplada in effigie - caso das reconstruções visuais, tais como desenhos, pinturas, fotografias, esculturas - ou in corpore, mas em qualquer caso o corpo é o mediador indispensável da pessoa. Entretanto, observa o autor, a imagem do ser humano e a imagem do corpo fazem parte de temas distintos. Com efeito, podemos constatar que uma das características da anatomia moderna é a de que ela se baseia em imagens que reconstroem 
corpos que não são pessoas. Esta era uma questão praticamente inexistente antes do século XVI, porque a produção e a transmissão do conhecimento anatômico e fisiológico eram estritamente baseadas na palavra: "a necessidade de figuras anatômicas era tão pequena que Mondino publicou seu muito usado e famoso manual de anatomia humana [originalmente] sem ilustrações" (Choulant 1920:27; tradução minha).

Até o advento da anatomia moderna, a autoridade da palavra era tamanha que suas descrições condicionavam e até se sobrepunham ao que era visto nas raras dissecações medievais. Mondino, apesar de ter dissecado seres humanos, sustentava que o "estômago é esférico, o fígado é constituído de cinco lobos, ${ }^{1} \mathrm{o}$ baço secreta bile negra através de canais imaginários [...]" (O'Malley 1964:13; tradução minha); Jacopo Berengario de Carpi (1460-1530) argumentou que o fígado humano pode ter "cinco lobos, algumas vezes quatro ou três, outras vezes dois"; e Iacobus Sylvius (1478-1555), responsável por boa parte da terminologia adotada na anatomia moderna e de quem Vesalius foi discípulo, sustentava que as divergências entre a descrição galênica e as dissecações medievais eram "resultado da posterior decadência e degeneração da espécie humana" (Saunders \& O'Malley, 2003:19, tradução minha).

Sinal da mentalidade mecanicista que se espraiava na época, é notável que a obra precursora da anatomia moderna, Da estrutura do corpo humano [De humani corporis fabrica], de Andreas Vesalius, e a obra que desarticulou o cosmos antropocêntrico, Das revoluções das esferas celestes [De revolutionibus orbium cœlestium], de Nicolau Copérnico, tenham sido publicadas no mesmo ano de 1543. Até então, a Terra era inquestionavelmente o centro do cosmos, os corpos celestes se fixavam em esferas homocêntricas e, na parte mais externa do universo, além do firmamento criado no segundo dia (Gênesis 1:6-7), acreditava-se que ficava o Cœlum Empyreum, o Céu que é o produto do primeiro ato da criação — " "no princípio Deus criou o Céu e a Terra" (Gênesis 1:1) — interpretado como "o recipiente último do universo e morada de Deus e dos eleitos" (Hoskin 1999:76; tradução minha). Nessa cosmologia, o corpo humano era visto como produto do mesmo processo de criação divina e concebido como um microcosmo que espelha simbolicamente os elementos que constituem a matéria e a organização dos corpos celestes.

Na visão holística da cosmologia medieval, a doença estava ligada ao pecado ${ }^{2}$ e ao desequilíbrio dos humores corporais no $\operatorname{corpo}^{3}$ e, por conseguinte, ao lado do cuidado com a alma, as terapias curativas focavam o restabelecimento do equilíbrio humoral por meio de purgantes ou sangrias. Concomitante ao esquema humoral, também se aplicava ao corpo o esquema da melotésia, ou a projeção e a subordinação do corpo à ordem dos objetos celestes. De acordo com a melotésia planetária, os planetas 
estão relacionados com a lateralidade corporal e têm influência sobre determinados órgãos:

Saturno é o "senhor do ouvido direito, do baço, da bexiga, da fleuma e dos ossos", Marte controla "o ouvido esquerdo, veias e os genitais". O Sol controla (dentre outras coisas) os olhos e "todas as partes da mão direita", enquanto Mercúrio controla a língua e "todas as partes da mão esquerda" (Ptolomeu apud Hall, 2008:75-76; tradução minha).

A melotésia zodiacal, por sua vez, consiste em projetar linearmente no corpo, da cabeça aos pés, 12 regiões que correspondem respectivamente aos signos do anel zodiacal:

[...] Áries domina a cabeça e o cérebro; Touro influencia o pescoço; Gêmeos domina os braços e os pulmões; Câncer está ligado ao tórax; Leão [...] influencia o coração; Virgem domina os intestinos e o baço; Libra está ligado aos rins e à região lombar; Escorpião é o signo dos órgãos genitais; Sagitário influencia o fígado, o nervo ciático e as coxas; Capricórnio está ligado ao joelho e às articulações; Aquário domina os tornozelos e a circulação; e Peixes influencia o pé (Battaglia, Miglietta \& Wenig-Lynds 2009; tradução minha).

Esse esquema corporal foi imageticamente padronizado no início da era cristã no "homem zodiacal", figura recorrente em tratados e enciclopédias astronômicos, teológicos, filosóficos e medicinais medievais (Bober 1948:3), tais como as ilustrações encontradas no Très riches heures of the Duke of Berry (figura 5) — que contém um calendário com signos do zodíaco relacionados tanto com o tempo como também com as correspondentes partes do corpo, ao centro do quadro - e no Fasciculo de medicina (figura 6), este com recomendações que evidenciam a continuidade entre o corpo e o cosmos: "capricórnio é o signo do mês de dezembro; não é bom tratar do joelho ou de seus nervos"; "câncer é signo de junho, evite tratar o estômago, baço, pulmões e os olhos"; "quando a lua está no signo de libra, é bom sangrar [...]; não é bom tratar do estômago e dos rins".

O homem zodiacal é evidência de que, como observa Le Breton (2011:49-50), na perspectiva medieval, "as fronteiras da carne não demarcam os limites da mônada individual" e que nela não há:

[...] qualquer ruptura qualitativa entre a carne do homem e a carne do mundo. O princípio da fisiologia humana está contido na cosmologia. [...] O corpo não é um universo independente, fechado em si mesmo, à imagem do modelo anatômico, dos códigos de saber-viver ou do modelo mecanicista. 
O cosmos anunciado por Copérnico já é um cosmos desencantado, pois em sua concepção já não há esferas mágicas de cristal que sustentem os planetas e nem lugar divino depois do firmamento. Na trilha aberta por ele, Isaac Newton reelaborou todo o universo como um grande maquinário regido por leis mecânicas cujo moto perpétuo é garantido pela gravitação universal. No cosmos newtoniano, que continua sendo a visão predominante até hoje, não há espaço para o sujeito transcendente e nem milagres, pois, como observa Kuhn (1985:263; tradução minha), supor a possibilidade da "intervenção de Deus e seus anjos nos assuntos terrestres" implica supor também a "suspensão da lei mecânica". O cosmos newtoniano é concebido como o mecanismo de um relógio e, a despeito de Sua colossal obra, Deus é reduzido à imagem do relojoeiro: "o Ser que moldou as partes atômicas estabeleceu as leis de seu movimento, colocou-os para trabalhar e então os deixou rodando sozinhos".

Foi nesse contexto de ruína do cosmos medieval e da articulação de uma nova visão de universo que o corpo passou a ser visto como uma máquina cuja mecânica é "discernível das outras pela exclusiva singularidade de suas engrenagens", não sendo "mais do que um capítulo da mecânica geral do mundo" (Le Breton 2011:120). Igualmente avessos às causas transcendentes, os anatomistas passaram a explorar as estruturas recônditas do corpo humano para compreender o seu funcionamento. Porém, se a evidência astronômica é, em última instância, a observação direta ou indireta da dinâmica celeste, o conhecimento anatômico — salvo raras exceções — é um processo de engenharia reversa que se fia quase exclusivamente na observação da estrutura morta para, posteriormente, extrapolar o conhecimento adquirido aos corpos vivos.

As dissecações que eram, até a Renascença, raros e solenes rituais de reafirmação do conhecimento e da hierarquia escolástica, generalizam-se a partir do século XVI e tornaram-se uma espécie de evento social, adquirindo os primeiros traços de espetáculo. O caráter espetacular da exibição de corpos humanos anatomizados se anunciava na época de Vesalius, pois já se usavam estruturas provisórias que precederam as características salas em forma de anfiteatro das escolas médicas ${ }^{4}$ (Saunders \& O'Malley 2003:50), construídas para abrigar plateias cada vez maiores. Le Breton (2011:78-79) observa que as dissecações acabam transbordando:

[...] sua intenção original para ampliarem-se à maneira de um espetáculo à curiosidade de um auditório heterogêneo. Os teatros anatômicos são mencionados nos guias de viagem. M. Veillon cita um texto de 1690, que relata a presença regular de quatrocentos a quinhentos espectadores nos jardins do rei. 
Lembramo-nos, aliás, da proposta de Diafoirus à Angélique, em O doente imaginário [La maladie imaginaire]: "Com a permissão também do senhor, eu vos convido a vir ver um dia desses, para vos divertir, a dissecação de uma mulher sobre a qual eu devo refletir" (Ato II cena V). As mentalidades desse século [XVI] tornaram-se hospitaleiras a fato que teria enchido de horror os homens das épocas anteriores [...].

As dissecações, mesmo tornando-se mais comuns e acessíveis a mais pessoas, eram, contudo, limitadas pela escassez de corpos elegíveis para a dissecação e pela deterioração do cadáver, o que restringia a dissecação às estações frias. Foi para fazer frente a essas contingências que ocorreu a interseção entre anatomia e arte, na forma dos desenhos anatômicos que incorporam as técnicas renascentistas e passam a ser largamente usados como sucedâneo da dissecação, tornando perenes as imagens das estruturas humanas por ela revelada. Antes mesmo da obra de Vesalius, diversos tratados anatômicos já faziam uso da imagem de corpos dissecados. As mais antigas representações figurativas da anatomia humana estão na edição de 1493 do Anathomia corporis humani, de Mondino, que contém ilustrações do órgão reprodutor feminino, provavelmente produzidas a partir da observação de estruturas anatômicas reais (Saunders \& O'Malley 2003:27).

Outras obras da época demonstram que essa já era uma tendência: Spiegel der Artzny (figura 8), de Laurentius Frisius, publicado em 1518, contém ilustrações com uma linguagem visual, técnica e qualidade estética que só viriam a ser superadas por Vesalius; Anathomia (figura 9), de Jacopo Berengario da Carpi, publicado em 1536, possui gravuras anatômicas em qualidades e fidelidades diversas, sendo que algumas se destacam por colocar o corpo dissecado em pose de gente viva, estética que Vesalius tornaria famosa; Johann Dryander, professor de anatomia de Marburg, foi também um dos pioneiros na inclusão em seu tratado, Anatomia Capitis Humani (figura 10), publicado em 1536, de ilustrações feitas a partir de suas próprias dissecações.

Talvez o mais conhecido anatomista renascentista depois de Vesalius tenha sido Leonardo da Vinci. As anotações de Leonardo indicam que ele pretendia produzir um tratado anatômico para o qual acreditava ser necessário dissecar 15 cadáveres masculinos e três femininos (da Vinci apud Kickhöfel 2011b:409). Como antecipam os desenhos anatômicos que produziu de 1485 a 1515, ele buscou representar o corpo de forma análoga àquela aplicada por ele aos estudos e projetos de máquinas, com a mesma lógica de vistas ortogonais, cortes esquemáticos (figura 7) e visões explodidas. Da Vinci, ao mesmo tempo em que "anatomizou" suas máquinas (Kickhöfel 2011a:344-346), 
também lançou sobre os corpos - de animais e de seres humanos - um olhar que os iguala a sistemas de dispositivos. Seus estudos, ainda que incipientes, já mostram o corpo desmantelado em partes, de acordo com uma taxonomia funcional, e representado com os mesmos recursos visuais usados em plantas e projetos de edifícios e máquinas.

Os estudos produzidos por da Vinci não evoluíram para um tratado de anatomia e permaneceram sem publicação por séculos, de forma que coube a Vesalius consolidar a transição de um saber sobre o corpo baseado na palavra para um saber baseado na imagem. É a partir da publicação de A estrutura do corpo humano que a imagem passa a ser a mediação fundamental pela qual o corpo se torna cognoscível, mais especificamente como a imagem de um objeto compreendido por meio de um viés mecânico e representado dentro de padrões geometrizados e matematizados.

Algo já anunciado nos trabalhos de da Vinci, Vesalius problematiza o corpo como uma questão de arquitetura e engenharia, reduzindo-o ao estatuto de artefato, máquina a ser desvendada. Vesalius, por exemplo, complementa as inúmeras imagens da coluna e de vértebras de seu tratado dizendo que:

A natureza, pai de todas as coisas, talhou a espinha do homem [figura 13] como um tipo de quilha e fundação. Por meio da espinha é que podemos andar de pé e ficar eretos. [...] Para proporcionar um caminho para a medula dorsal e ao mesmo tempo ser flexível, primeiro, ela esculpiu o foramen [foramen vertebrale, no original] em todas as vértebras [...], preparando um apropriado caminho descendente para a medula dorsal [medula spinalis, no original]. Segundo, ela não fez toda a espinha como um indivisível e simples osso, embora isso fosse suficiente para a estabilidade e um lugar seguro para a medula dorsal [...]. Mas para o ser humano que curvará sua espinha para baixo ou a tornará ereta, não é de forma alguma bom que toda ela seja formada por um simples osso; de fato, [...] foi melhor ela ser composta por diversos ossos, não importa o quanto, por esta razão, ela tenha sido feita mais vulnerável a danos (2003:57-58, tradução minha).

Ao propor uma "representação médica do corpo que não é mais solidária com uma visão simultânea do homem" (Le Breton 2003:18), Vesalius promoveu uma ruptura radical. Mais do que apartá-lo do tecido cosmológico, a partir de Vesalius, a desmontagem do corpo tornou-se requisito fundamental para o seu entendimento. Observa Coli (2003:300) que, com o predomínio da visão de que "as partes, organizadas e em função, produzem o todo", assistimos "ao adentrar pela cultura dos últimos séculos, a um fascínio pelo humano que se desmembra". Conclui Coli: "cria-se, por assim dizer, uma poética do fragmento". 
A assepsia, a fragmentação e a impessoalidade introduzidas por Vesalius na ilustração anatômica são recursos que produzem o correspondente visual do "distanciamento clínico" [clinical detachment], "a habilidade de olhar o cadáver humano como um objeto de estudo" (Richarson 2000:3031, tradução minha), postura que começa a ser operacionalizada no período em que as dissecações florescem: fim da Idade Média e início da Renascença. Codificados em modelos sem vínculos de pessoalidade e que enfatizam o caráter fragmentário de sua constituição, o corpo anatomizado é aquele destacado da existência humana e domesticado como artefato, logo destituído do simbolismo que conecta a carne e o sangue à impureza da alma. É um corpo que não representa de fato nenhum dos corpos nos quais tenham se baseado as observações, ou qualquer outro corpo real, mas sim um constructo de corpo genérico, uma espécie de gabarito, que mostra como as partes devem estar combinadas no ser humano, tais como peças que, montadas, compõem a totalidade de tal ou qual máquina. A diversidade dos corpos humanos reais é, nesta perspectiva, somente produto da variação de seus componentes, já que "a estrutura do corpo humano" é concebida como invariável.

Paradoxalmente, o constructo anatômico vesaliano, ainda que ancorado principalmente na reconstrução imagética aparentemente tão fiel quanto possível de corpos reais, não corresponde ao corpo de ninguém, mas a um modelo ideal. Isto contrasta com o encontrado em um conjunto significativo de desenhos anatômicos produzidos por Leonardo da Vinci, entre 1507 e 1508, que são evidentemente de alguém específico: caso em que a representação do corpo também representa a pessoa (figura 8). Essa pessoa é chamada nos seus manuscritos de "o Velho" e acredita-se que da Vinci tenha conversado com ele antes de dissecá-lo (Kickhöfel 2011a:347; Carreira 2000:23).

Siarisi (1994:70) comenta que esse aspecto individualizante da representação corporal também é encontrado em trabalhos mais antigos de Vesalius, tais como os desenhos conhecidos como Tabulae anatomicae sex, que reproduzem os "defeitos do espécime individual do qual foi desenhado". Em Da estrutura do corpo humano (De Humani Corporis Fabrica, mais conhecido como Fabrica), ao contrário, já não há mais reminiscência da inseparabilidade entre corpo e indivíduo, pois o que é representado não é mais o corpo de alguém especificamente, mas uma abstração, um constructo produzido a partir da dissecação de inúmeros corpos. Com efeito, o esqueleto do tratado "teve suas proporções ajustadas para coincidir com os cânones artísticos contemporâneos [renascentistas] de proporções do corpo humano ideal": "a Fabrica estabelece o assunto da scientia da anatomia como uma versão padronizada do corpo humano natural/saudável — nem criança e 
nem velho, inalterado em tempo, povo ou cultura e homem até que seja especificado como mulher" (Siraisi 1994:87, tradução minha).

Apesar de ter sido publicado antes de O discurso do método (Descartes 1999 [1637]), Da estrutura do corpo humano possui íntima afinidade com o pensamento cartesiano. Leite Brandão (2003:293) afirma que o projeto de Vesalius é similar ao cartesianismo, no qual corpo e universo, totalmente distintos do cogito constituinte do sujeito, são reduzidos "às propriedades geométricas e mecânicas passíveis de serem compreendidas e manipuladas pelo espírito". Nas palavras do próprio Descartes (1999:62), a natureza do corpo se opõe à natureza da pessoa, pois esta consiste "apenas no pensar e que, para ser, não necessita de lugar algum, nem depende de qualquer coisa material". Le Breton (2003:18), por sua vez, nos lembra que Descartes, ao desligar a "inteligência do homem da carne", transformou o corpo apenas no "invólucro mecânico de uma presença" que, no limite, "poderia ser intercambiável, pois a essência do homem reside, em primeiro lugar, no cogito". O autor acrescenta que:

Descartes formula com clareza um termo-chave da filosofia mecanicista do século XVII: o modelo do corpo é a máquina, o corpo humano é uma mecânica discernível das outras apenas pela singularidade de suas engrenagens. Não passa, no máximo, de um capítulo particular da mecânica geral do mundo (Le Breton 2003:18).

As exposições de corpos plastinados reproduzem a imagem vesaliana do corpo como soma de subsistemas, uma máquina anatômica que nada mais é do que a res extensa separada da alma e objeto da razão humana, um corpo primariamente "visto como um objeto material do qual as propriedades anatômicas e funcionais podem ser caracterizadas de acordo com a lei científica" (Leder 1990:5, tradução minha). Essas formulações e representações mecanicistas do corpo têm grande afinidade com o postulado cibernético de que não há distinção entre máquina e organismo. O fundador da cibernética, Norbert Wiener (1948), foi, para Le Breton (2003:182), o "primeiro a embaralhar as fronteiras do autômato e do vivo", levando a novas formas de pensar o corpo. No contexto social atual, no qual o corpo é corriqueiro objeto de intervenções para receber implantes e transplantes, a exibição de "espécimes" humanos plastinados fornece a ilusão que ratifica tanto a concepção cartesiana do corpo como a visão cibernética de que o corpo é um sistema de peças que são, em princípio, passíveis de serem substituídas por equivalentes ou melhoradas, tendo em vista o seu desempenho e de acordo com as possibilidades tecnológicas em permanente evolução (cf. Kim 2005:53). 
Figura 5 - Ilustração de homem zodíaco do Très riches heures du Duke of Berry, produzido entre 1411 e 1416

Figura 6 - Ilustração do homem zodíaco publicado no Fasciculo de medicina de Johannes Ketham, em 1494
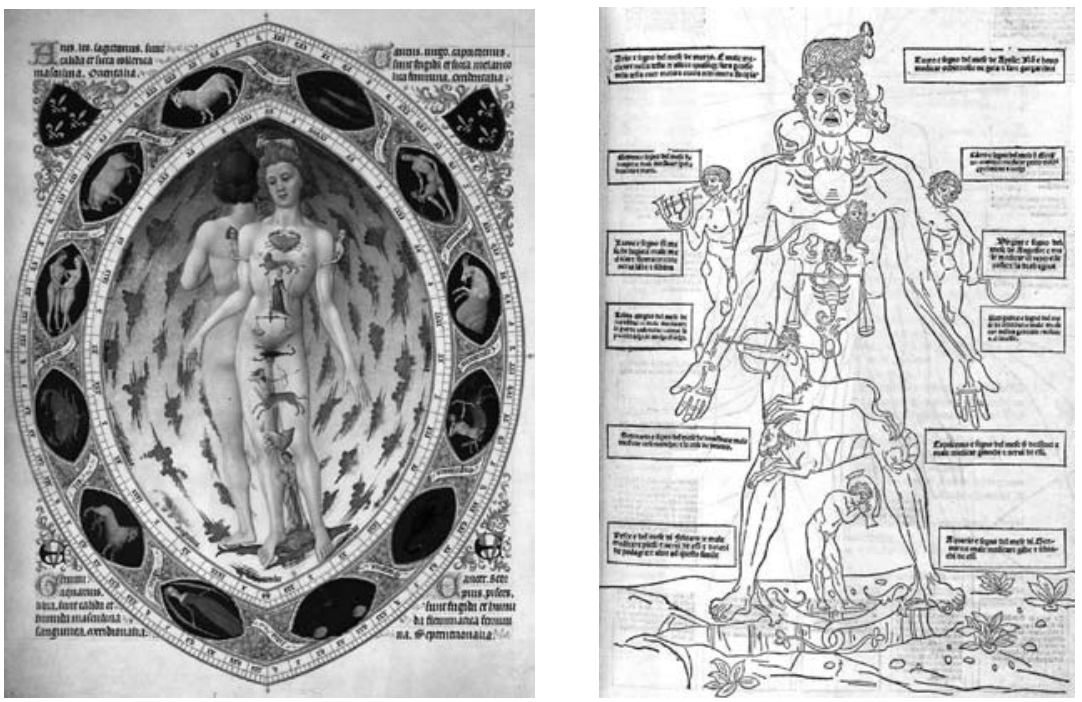

Figura 7 - Corte esquemático de crânio humano produzido por Leonardo da Vinci Figura 8 - Desenho de Leonardo da Vinci de O Velho, produzido entre 1510 e 1511
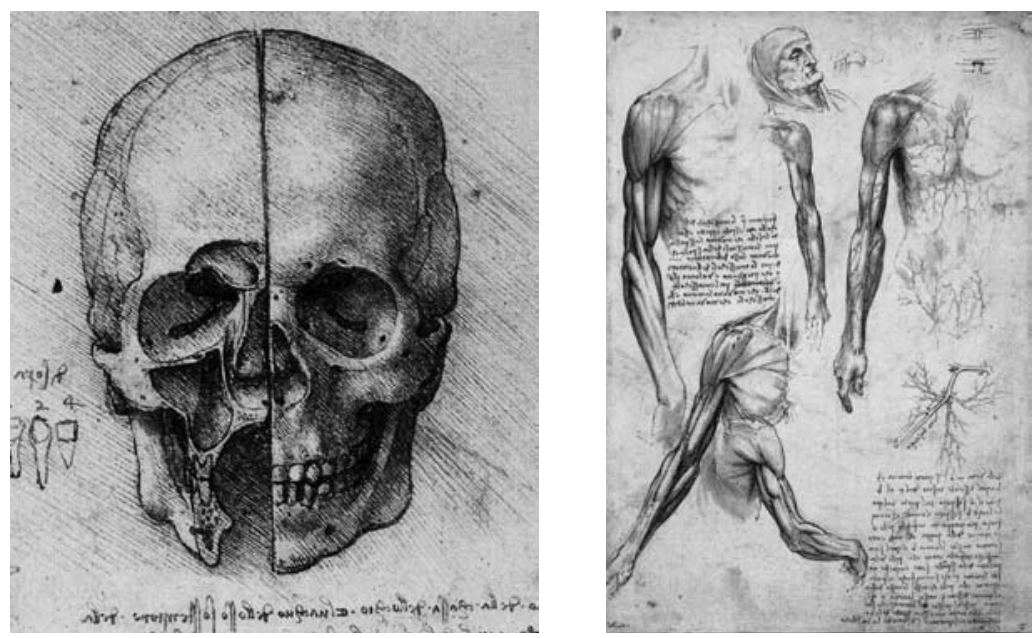
Figura 9 - llustração anatômica de Laurentius Frisius, de 1517

Figura 10 - Ilustração anatômica de Berengario da Carpi, de 1523
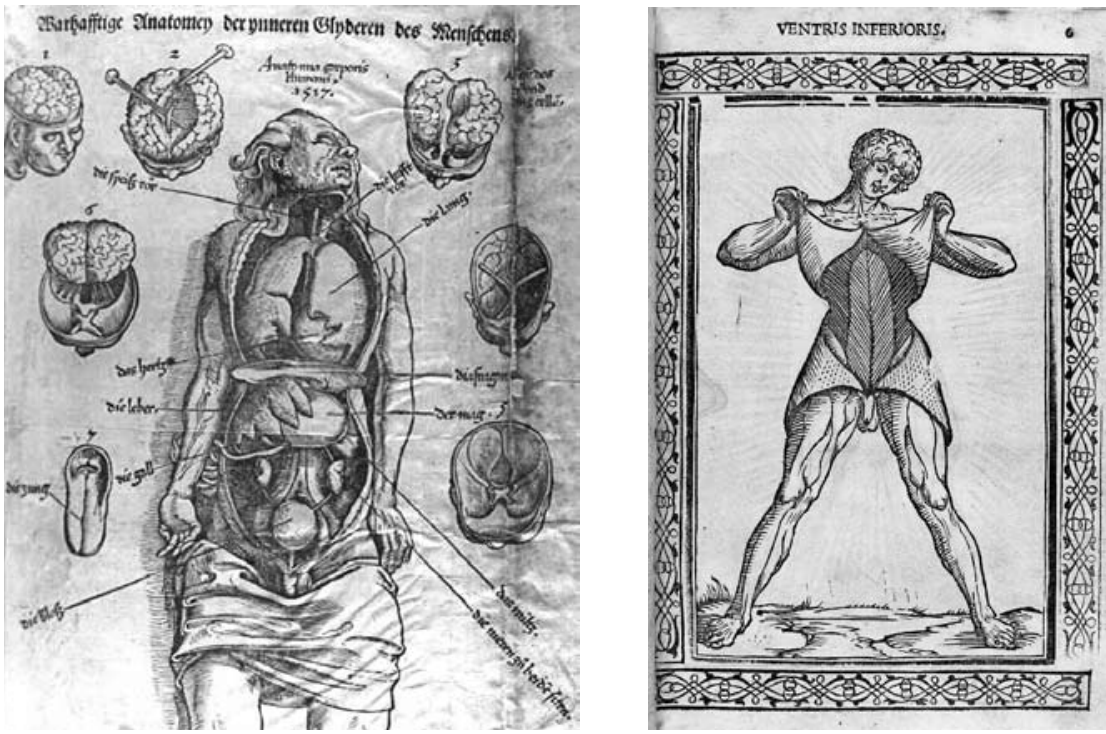

Figura 11 - Ilustração anatômica de Johann Dryander, de 1536

Figura 12 - llustração anatômica de Andreas Vesalius, de 1543
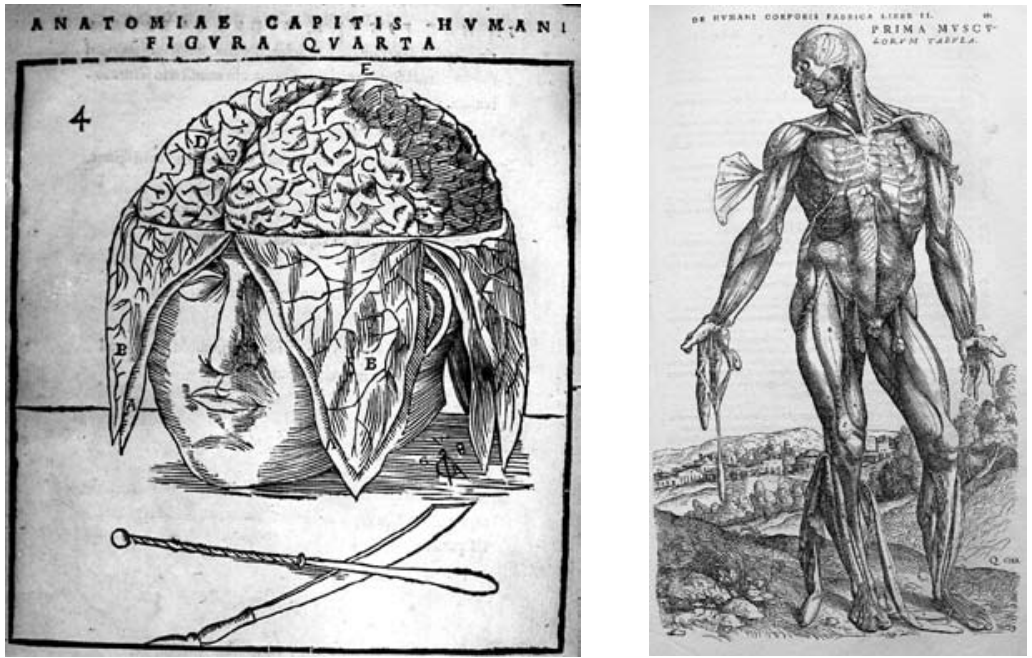


\section{Sobre a impureza simbólica e a utilidade do cadáver-mercadoria}

Utilidade e propriedade do corpo são desdobramentos lógicos da distinção entre corpo e pessoa, a res cogitans e a res extensa da formulação cartesiana, que se traduzem concretamente na relação com o corpo como uma propriedade. A venda da força de trabalho em troca do salário nada mais é do que um dos aspectos do corpo-utilidade. A exploração utilitária do corpo, porém, não termina com a sua morte.

Desde que a dissecação humana é praticada, o cadáver propriamente dito tornou-se útil, em especial, mas não exclusivamente, ${ }^{5}$ por causa da sua apropriação no processo de formação de médicos e cirurgiões. Como observa Richardson (2000:50):

[...] para o estudo da anatomia e da cirurgia, era necessário ao médico desenvolver [...] o "distanciamento clínico" [clinical detachment] [...] — uma vez morto, o corpo humano [...] pode ser mais prontamente objetivado do que o corpo de um paciente gritando e se contorcendo. Essa facilidade de objetivação sublinha o motivo pelo qual na década de 1830 a anatomia e particularmente a dissecação foram promovidas como a base constitutiva de todo conhecimento científico do corpo humano.

A afinidade entre a prática da dissecação e do roubo de tumbas tem a ver com a demanda reprimida, sempre maior do que a oferta de cadáveres regulamentada por lei, problema histórico que acompanha a anatomia desde os seus primórdios. O registro mais antigo de roubo de tumba para fins atômicos é de 1319, perpetrado por quatro estudantes bolonheses (O'Malley 1964:14; Park 2009:48). Richardson (2000:54) observa que, no século XVIII, cadáveres dos cemitérios ainda eram roubados pelos próprios cirurgiões e anatomistas, em particular por estudantes incentivados pelos seus professores e tutores e que, por volta de 1720, "o roubo de corpos das tumbas de Londres era praticamente lugar comum". Foi no período de 1675 a 1725 que provavelmente, complementa a autora, "o corpo humano passou a ser comprado e vendido como qualquer outra mercadoria ou, caso contrário, traficado", sendo que "por volta de 1800, nos círculos médicos, a terminologia comercial era aplicada aos corpos humanos sem aparente constrangimento".

Ainda que fosse de fato tratado como mercadoria, o corpo não era legalmente uma "propriedade" (Richardson 2000:58), fator que incentivava o roubo e o tráfico de cadáveres. Em 1822, Cobbet (apud Richardson 2000:58) observou que "o roubo do corpo de uma ovelha, porco, bezerro, boi, galinha é 
um delito capital, punido com a morte", enquanto "a receptação de qualquer corpo, posse dele, sabendo-se que foi roubado também é um delito, [mas] punido com deportação".

Historicamente a elegibilidade de um corpo para dissecação está relacionada com a aplicação da pena capital, pois ela é análoga às outras formas de punição que existiram até o século XVIII, tal como o desmembramento. ${ }^{6}$ Segundo Le Breton (2011:54), a lógica deste tipo de punição está em infligir metaforicamente no corpo do criminoso o desmembramento do corpo social. Dividir o corpo de quem perpetra um crime considerado grave era castigo aplicado em diversos locais e extrapolou a Idade Média. Na Inglaterra, ser enforcado, arrastado e esquartejado [hung, drawn and quartered] constituiu a pena padrão reservada aos condenados por alta traição, de 1283 a 1867 (Roza 2011:8). Foucault, em Vigiar e punir (1999:9) descreve o suplício de Damiens. Ocorrido no ano de 1757, ele foi condenado a ser

atenazado nos mamilos, braços, coxas e barrigas das pernas [e a ter aplicado nessas partes] chumbo derretido, óleo fervente, piche em fogo, cera e enxofre derretidos conjuntamente, [antes de finalmente ser] puxado e desmembrado por quatro cavalos e seus membros e corpo consumidos ao fogo, reduzidos a cinzas, lançadas ao vento.

De acordo com Foucault (1999:9), a fase do desmembramento resultou em uma operação muito longa, "porque os cavalos utilizados não estavam afeitos à tração", sendo necessário, "para desmembrar as coxas do infeliz", mais dois cavalos, além de "cortar-lhe os nervos e retalhar-lhe as juntas". Evidência da inseparabilidade entre pessoa e corpo é o fato de que o desmembramento não era necessariamente uma pena aplicada ao condenado vivo, mas também aplicada como pena suplementar, após sua execução. É o caso de Tiradentes, sentenciado em 1792 à morte por enforcamento seguido da exibição pública de sua cabeça, pregada em um poste alto de Vila Rica, "até que o tempo a consuma", e dos quartos de seu corpo "pregados em postes pelo caminho de Minas [...] onde o réu teve suas infames práticas [...] até que o tempo também os consuma" (Arquivo Nacional 2007).

A dissecação inseriu-se, portanto, em uma lógica já estabelecida de castigos corporais, sendo que, na Inglaterra, ela chegou a ser oficialmente aplicada como punição adicional à pena capital: "punição violentamente impopular" (Richardson 2000:53), ter o corpo dissecado era pena considerada "mais temida e ignóbil por muitos ofensores e seus familiares do que a execução propriamente dita" (Hunter ${ }^{7}$ apud Hildebrandt 2008:7; tradução minha). Na base dessa aversão está a inseparabilidade do corpo e da alma, 
Figura 13 - llustração anatômica de Andreas Vesalius, de 1543

Figura 14 - Ilustração anatômica de Valverde de Amusco, de 1560
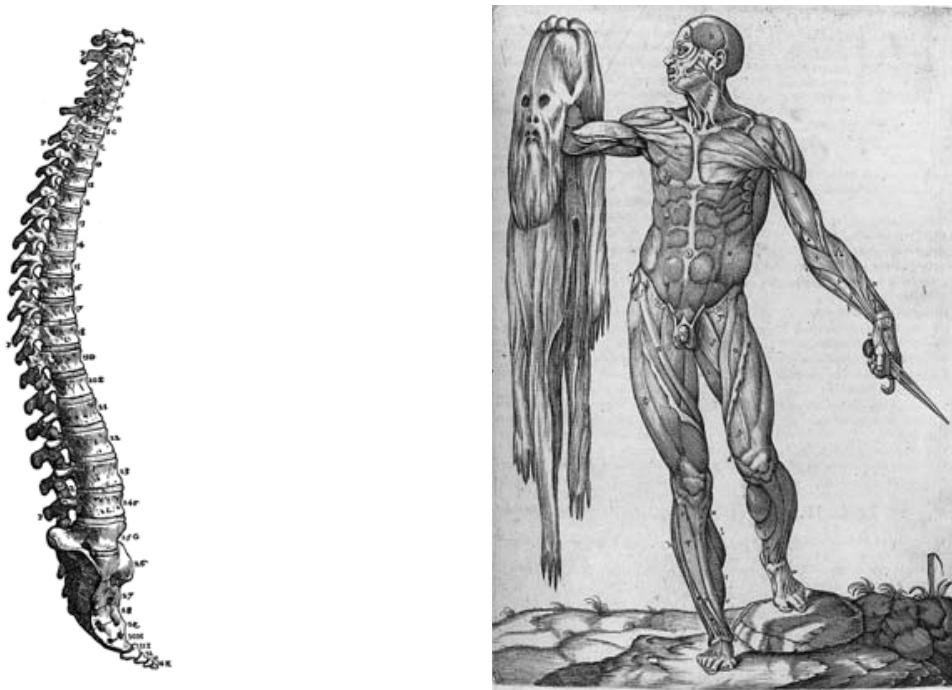

Figura 15 - Ilustração anatômica de Govard Bidloo, de 1685

Figura 16 - Ilustração anatômica de Siegfried Albinus, de 1749
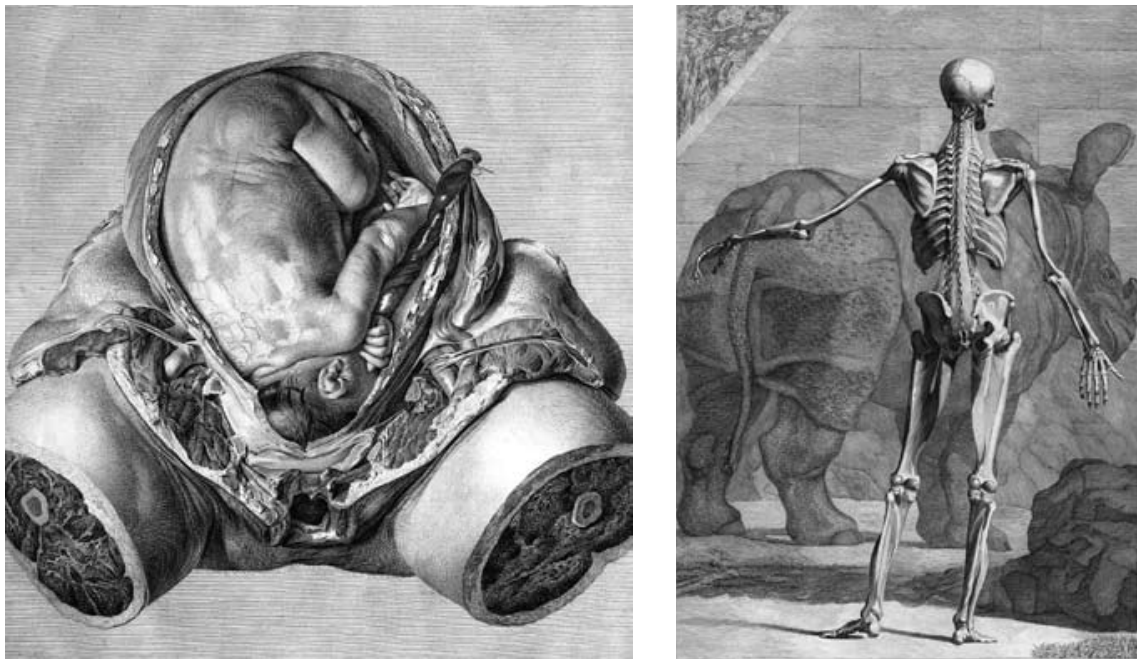
fato ratificado pelo IV Concílio de Latrão, em 1215, que postulou ser "o homem verdadeiro composto de uma alma racional e carne humana" (Twelfth Ecumenical Council 1937, tradução minha). Fabricado por Deus no início dos tempos, o corpo também é a mediação inalienável entre a pessoa e a vida eterna no Juízo Final, pois nesse dia Deus conduzirá os escolhidos para "uma ressurreição eterna de vida" (II Macabeus 7:9) e o corpo ressuscitado será incorruptível (I Coríntios 15:42). Na visão tradicional cristã, a morte é apenas a suspensão da pessoa, uma separação transitória do corpo e da alma que se recombinarão no dia do Juízo Final.

A dissecação é vista como algo ignóbil e indigno porque resulta na desintegração do corpo, o que, além de ser percebido como um risco à sua ressurreição, viola a integridade pessoal e social da pessoa e de seus parentes e transforma o cadáver em "algo irreconhecível e inadequado para um funeral convencional" (Park ${ }^{8}$ apud Hildebrandt 2008:6, tradução minha). Daí a busca por corpos de indigentes, pessoas que não estejam inseridas na trama da sociedade, traduzida nas regulamentações mais antigas na figura do forasteiro, definido como alguém "nascido há mais de 48 quilômetros [30 milhas]" (Park 2009:48, tradução minha). O corpo do forasteiro era aquele que não seria reclamado por ninguém, logo, um corpo sem dono e disponível para ser apropriado por outrem. A regulamentação do governo de Bologna, em 1442, ilustra bem a lógica que busca corpos entre aqueles que atentam contra a ordem social ou que não fazem parte dela: os dois corpos a serem disponibilizados anualmente para dissecação deveriam ser de "criminosos estrangeiros - ou seja, não bolonheses — executados" (O'Malley 1964:15, tradução minha). A articulação desse duplo critério de marginalidade social, a indigência e a criminalidade, é o filtro básico que define quem é potencial objeto de aulas de anatomia até os dias de hoje.

Seguramente, mesmo para muitas das ditas sociedades modernas, imaginar o próprio corpo ou o corpo de um ente querido sendo dissecado e exposto publicamente é repugnante e grotesco. Entretanto, os casos de doação do próprio corpo para a dissecação científica e mesmo para exibição pública não são inéditos e nem raros. Jeremy Bentham, o famoso filósofo utilitarista, deixou instruções em testamento doando seu próprio corpo ao amigo e médico Southwood Smith para ser dissecado, preservado, vestido com as roupas usuais e sentado "na cadeira que ocupou quando vivo" em uma instalação que denominou de "Auto-Ícone" (Cf. Bentham 1832, tradução minha) e que está exposta até hoje no University College London. Originalmente, Bentham desejava que sua cabeça fosse parte do Auto-Ícone, mas como a técnica de preservação aplicada foi mal sucedida, uma cabeça de cera foi usada no lugar da original (University College London 2010). 
Além da possível vaidade que motivou o desejo de se expor pela eternidade, Bentham atendia ao apelo feito anos antes pelo seu amigo médico "ao público e à legislatura sobre a necessidade de prover corpos mortos às escolas de anatomia" (Smith 1827:3, tradução minha). É o mesmo apelo utilitário que faz o programa de doação de corpos de von Hagens (Institute for Plastination 2007, tradução minha), que conta com 12.000 doadores (Hamburg 2010) espalhados pela Europa e pelos Estados Unidos: "Doar corpos para a plastinação permite que indivíduos contribuam para a educação de futuros profissionais da medicina e numa forma especial, como espécimes que ficarão permanentemente disponíveis para os médicos e os leigos".

Contrasta com o visível caráter utilitário que o corpo tem nas sociedades modernas e high-tech o fato de que, mesmo nelas, os mortos são considerados poluentes, fontes de tabu e mana. Como a irreversibilidade da morte é aquilo que, no limite, nos diferencia das máquinas e representa um estado corporal que é incompatível com o sistema de valores centrado na apologia ao desempenho e à superação dos limites da carne, pode-se afirmar que o tabu em relação aos mortos é até mesmo mais agudo nas sociedades modernas.

A plastinação - o processo técnico — não possui apenas a eficácia físico-química de deter a putrefação do corpo e transformá-lo em um fóssil sintético. Ao viabilizar que corpos sejam esculpidos e preservados da mesma forma como estão representados nos clássicos tratados de anatomia, ou mesmo de forma mais ousada, a plastinação é incorporada como elo de uma cadeia de procedimentos simbólicos que reafirmam a visão cartesiana de que o corpo nada mais é do que matéria, a res extensa, simples extensão da coisa pensante identificada com o "eu", a res cogitans. Assim, para exibir cadáveres como se eles fossem máquinas sem alma, os procedimentos que transformam gente morta em coisa têm uma dimensão simbólica que é, de certo modo, análoga aos procedimentos rituais de desagentivação utilizados pelos indígenas amazônicos para converter a caça em comida.

Fausto (2002:9) observa que, na perspectiva desses povos, tanto animais como seres humanos compartilham do mesmo estatuto ontológico, de forma que "a intencionalidade e a consciência reflexiva não são atributos exclusivos da humanidade, mas, potencialmente, de todos os seres do cosmos". Como nessas sociedades é difundida a concepção de que a predação resulta na identificação entre predador e presa - entre quem come e aquilo que é comido - é necessário reduzir o animal-sujeito a animal-objeto para produzi-lo como comida. Caso contrário, a consubstanciação da parte sujeito do animal com o devorador humano expõe este último a um processo de contrapredação por parte da espécie animal, e que consiste em assimilar a alma do devorador como um parente. Daí a importância, para os indígenas, 
dos procedimentos xamânicos que permitem "neutralizar ou reduzir a capacidade agentiva-transformativa do animal" e do fogo, largamente utilizado como redutor de animais-sujeitos a animais-objetos (Fausto 2002:16-18).

Em seu estudo sobre o canibalismo Wari', Vilaça (1992:66-70) observa que "para serem consumidos, animais com jam" — categoria que inclui as pessoas "devem ser destituídos daquilo que lhes confere a humanidade [...], ou seja, transformados em simples animais [...]". Para isso, tradicionalmente precisam ser observados por um xamã antes do consumo e passar por procedimentos de preparo adequados, nos quais a função do fogo é vital, já que "é concebido como um dissociador de corpo e jam: destruído o corpo, o jam se libera [...]".

Analogamente, a plastinação cumpre o procedimento simbólico de reduzir o corpo-pessoa para produzi-lo como corpo-objeto, basicamente empobrecendo-o ontologicamente e transformando-o em modelo anatômico que reproduz os limites epistemológicos da ciência. Tão importante quanto realçar aos nossos sentidos as características sintéticas proporcionadas pela plastinação, é negar as características de cadáver, omitindo tudo aquilo que não coadune com o estatuto de corpo-objeto. Assim, por meio do anonimato e de termos técnicos, busca-se também afastar da percepção imediata o universo social ao qual o morto-outrora-vivo está potencialmente conectado. Alega-se que o anonimato tem o objetivo de não expor a imagem do doador e de sua família, mas é inegável que isto também tem o efeito desejável de omitir a dimensão social do cadáver. ${ }^{9}$ Chamar pessoas e pedaços delas de "espécimes" — em lugar do seu nome, de "corpo", "pessoa" ou "indivíduo" — ratifica seu estatuto de artefato, coisa sem nome e sem dono, logo, disponível para ser apropriada.

Apesar de exibirem cadáveres, as exposições de corpos humanos refletem o esquema geral da modernidade, no qual os rituais relacionados à morte transformaram-se em tabus e foram expulsos da vida cotidiana. Aparente paradoxo, a espetacularização da morte nas sociedades que consideram abominável a execução em praça pública - em especial o suplício e o desmembramento, sobretudo quando seguidos da exibição dos restos cadavéricos do executado - é, na verdade, a negação da própria morte, assim como a pornografia sexual nega a própria sensualidade. A morte, como elemento nevrálgico de sociabilização vem desaparecendo das sociedades modernas: "Hoje é vergonhoso falar da morte e do dilaceramento que [a morte] provoca, como antigamente era vergonhoso falar de sexo" (Ariés 2012:210).

Reflexo desse afastamento da morte da vida social moderna, o contato com ela não é mais considerado parte da formação social das pessoas, visto que não é incomum crianças serem dispensadas de comparecer ao enterro de seus avós ou um jovem "atingir a idade adulta sem nunca ter visto alguém morrer" (Ariés 2012:234). Além disso, a pessoa que está para morrer é ge- 
ralmente isolada do convívio social e confinada em hospitais: "Cada vez se morre menos em casa e cada vez mais no hospital" (Ariés 2012:223). Elias (2001:15-17), por sua vez, argumenta que isso ocorre porque, em um mundo onde a morte está recalcada, o moribundo "abala as fantasias defensivas que as pessoas constroem como uma muralha contra a ideia de sua própria morte". Se antes, assim como o nascimento, a morte era pública (Ariés 2012:217; Elias 2001:25), esta é hoje privada do próprio moribundo:

O que devia ser conhecido é [...] dissimulado. O que deveria ser solene é escamoteado. É tácito que o primeiro dever da família e do médico é o de dissimular a um doente condenado a gravidade de seu estado. [...] O novo costume exige que ele morra na ignorância de sua morte (Ariés 2012:219).

Anonimato, descaracterização dos traços físicos associados a uma identidade pessoal, em especial a pele da face e das mãos, e a valorização do aspecto sintético atuam para destilar nos corpos plastinados apenas seus atributos biomecânicos, reafirmando, através deles, o apagamento da morte de fato, as palavras "morte" e "morto" nunca são usadas nas exposições e nos sites - da vida cotidiana.

Esse controle simbólico das exposições de corpos humanos não é, porém, livre de riscos, pois a impureza simbólica do cadáver se manifesta assim que surgem sinais de que algo escapou aos ritos de transformação - nativamente explicados como procedimentos tecnológicos e burocrático-legais do corpo-pessoa em corpo-objeto. Causa desconforto quando líquidos brotam ou pingam dos corpos plastinados, como o ocorrido na exposição "The Universe Within", em San Francisco (Barnum 2005), e na exposição "Bodies Revealed", em Sacramento (CBS 2008) ${ }^{10}$ — o que demanda imediatos procedimentos de purificação por parte dos institutos de higiene e de saúde pública para controlar um potencial perigo biológico. Esse perigo não é apenas biológico mas, antes disso, simbólico.

O fato de o público para o qual são exibidos os corpos plastinados raramente ter contato com cadáveres, em especial aqueles em estado de putrefação, não significa que os sinais de decadência do corpo sejam isentos de significado. O impuro é fundamentalmente aquilo que está fora de lugar (Cf. Douglas 2003:36). Isto é especialmente verdade no caso de um cadáver pingando líquido estar no espaço público de uma sociedade na qual, como nota Ariés (2012:240), as crianças não nascem mais dentro de repolhos [ou são trazidas pela cegonha], "mas são os mortos que desaparecem por entre as flores".

É um fenômeno praticamente universal o cadáver ser considerado impuro e altamente contaminante. Nas sociedades de tradição judaico-cristã, 
a matriz cosmológica fundamental do Ocidente, os interditos remontam ao Velho Testamento:

Quem tocar o cadáver de um homem qualquer será impuro sete dias [...]. Todo [aquele] que tiver tocado o cadáver de um homem qualquer, e não se purificar, manchará a casa do Senhor [...]. Não tendo corrido sobre ele a água lustral, ficará impuro, e sua impureza permanecerá sobre ele (Números 19:11-16).

Se alguém, em pleno campo, tocar em um homem morto pela espada, em um cadáver, em ossos humanos, ou em um sepulcro será impuro durante sete dias.

Hertz (1990:23-25) observa que a liberação de líquidos de cadáveres é um traço da putrefação recorrentemente associado a um estado cadavérico intermediário, no qual o morto é considerado um risco aos vivos. O autor argumenta que esse estado intermediário reside na "crença de que para enviar ao outro mundo um objeto material ou um ser vivo, para liberar ou criar sua alma, é necessário destruí-lo previamente" (Hertz 1990:43, tradução minha). A morte "definitiva", a consumação total da pessoa estaria, assim, ligada à extinção dos traços que caracterizam esse estado intermediário, em especial os líquidos cadavéricos. De acordo com esta tese, ossos e esqueletos que sobram ao fim do processo de putrefação, assim como as múmias, são simbolicamente menos perigosos, já que são corpos de pessoas "definitivamente mortas". Nativamente essa lógica é estendida aos corpos plastinados, como Walter (2004:613, tradução minha), argumenta sobre von Hagens:

\footnotetext{
Embora ele não tivesse contato com Hertz e sua terminologia [...], von Hagens desenvolveu sua própria terminologia e, notadamente, similar análise. Ele distingue cadáveres (corpos que se decompõem e que são normalmente velados), cadáveres molhados (espécimes anatômicos, múmias de pântano etc. que são estáveis apenas se mantidos em um fluido preservativo) e cadáveres secos (múmias, esqueletos, plastinados etc.) que são quase indefinidamente estáveis; sob circunstâncias normais, apenas o primeiro e o último (correspondendo ao esquema molhado e seco de Hertz) são encontrados.
}

Isso explica a baixa aversão que causam os corpos plastinados e por que a presença de traços associados à putrefação — tal como o gotejamento de líquido de um corpo plastinado, mesmo que sejam quimicamente inofensivos sejam interpretados como sinais de potencial agentividade que comprometem toda a cadeia de procedimentos de transformação do corpo-pessoa em corpoobjeto. Entretanto, tão desconcertante quanto o vazamento de líquidos que quebram a artificialidade dos corpos plastinados é o vazamento de informações 
que os vinculam a contextos sociais que, além de contrariar o caráter sintético imputado a eles, evidencia a afinidade que a plastinação, assim como a dissecação no passado, tem com o tráfico de partes humanas.

Declarações feitas por potenciais doadores (Sheter 26/02/2008) indicam que a intenção de ser útil após a morte e o desejo de ser de alguma maneira eternizado são algumas das motivações que sustentam essas doações, e que elas podem ser acomodadas de acordo com as expectativas religiosas dessas pessoas. Ao lado do utilitarismo - compartilhado por muitos espectadores que apreendem as exposições como educativas e informativas e não como algo abominável (Walter 2004:618) — o programa de doação de corpos da Body Worlds conclama as pessoas a doarem seus corpos prometendo na morte a existência espetacular que lhe foi negada em vida, ainda que a ética do anonimato subentenda que não existem garantias de que sequer farão parte do espetáculo. Na verdade, o programa de doação é mais uma estratégia de marketing amplamente utilizada para se esquivar da má fama que recai sobre a dissecação humana e para invocar um padrão ético que diferenciaria a Body Worlds dos concorrentes, em um cenário onde toda a indústria de corpos humanos plastinados é alvo de críticas acerca da origem duvidosa dos cadáveres.

O catálogo da exposição "Corpo humano: Real e fascinante" declara que "todos os corpos e órgãos vêm de indivíduos que optaram por doar seus corpos para a ciência médica com o propósito de estudo e educação" (Glover 2007:3), e a sinopse da exposição na versão brasileira no web site (Corpo humano: Sinopse 2007) acrescentava que eram "indivíduos acometidos de morte natural, que optaram por participar de um programa de doação de seus próprios corpos em benefício da ciência e da educação, realizado pela República Popular da China".

Contudo, dois anos antes, a Premier Exhibition, produtora desta exposição e de outra intitulada "Bodies... The Exhibition", já havia sido incapaz de comprovar o consentimento em vida das pessoas cujos corpos foram utilizados em sua exposição na Flórida. Em 2005 (Associated Press 2005), seu CEO, Arnie Geller, CEO da Premier Exhibitions, alegou que os corpos eram de chineses não identificados ou não reclamados e que era impossível provar que seu uso tenha sido autorizado previamente. A empresa também não conseguiu comprovar que os corpos de suas exposições não eram de pessoas executadas, sendo que, em 2008, o procurador geral de Nova York, Andrew Cuomo, emitiu uma resolução na qual afirma que "a cruel realidade é que a Premier Exhibitions lucrou exibindo restos de pessoas que podem ter sido torturadas e executadas na China" e que, apesar de ela negar repetidamente este fato, “a própria Premier não é capaz de demonstrar as circunstâncias da morte desses indivíduos" (New York State Attorney General 29/05/2008, tradução minha). 
Von Hagens, apesar de seu programa de doação, também é alvo de críticas, pois ele já declarou que somente os "plastinados posados, denominados espécimes de corpo inteiro [whole-body specimens]" são provenientes de doações e que, mesmo para este fim, no futuro, não seriam mais utilizados exclusivamente corpos doados. Seu programa de doação funciona como uma fachada que esconde o fato de que nem todos os "espécimes" de suas exposições são doados, mas que são também corpos não reclamados, em conformidade com a tradição e as leis do país de origem que são, por exemplo, a Rússia e a China (Cf. von Hagens 2003, tradução minha).

Ulaby (11/08/2006, tradução minha) observa que a política de anonimato não permite rastrear a origem dos corpos expostos pela Body Worlds e cita uma polêmica acerca de 56 corpos e centenas de amostras de cérebro enviadas a von Hagens da Academia Médica de Novosibirk, Rússia, e que foram rastreadas até um médico local condenado por "vender ilegalmente corpos de sem-teto, prisioneiros e pacientes indigentes". Todas as exposições que vieram ao Brasil enfatizaram o fato de que os cadáveres eram de chineses que doaram seus corpos em vida, algo notoriamente incompatível com a prática de culto aos antepassados. Justamente por não ser possível rastrear a origem, pesa sobre esse tipo de atividade grande suspeição em relação à maneira como sua matéria-prima fundamental, os cadáveres, são obtidos.

A predominância de traços asiáticos nos corpos das exposições de plastinados pode ser explicada pela fundação, em 2001, na cidade de Dalian, China, de uma grande unidade fabril de plastinação que contava, em 2006, com 260 empregados ganhando de 200 a 300 dólares por mês (Barboza 08/08/2006). Além do fator econômico, também é provável que o suprimento facilitado de corpos humanos tenha pesado na escolha do local. Hildebrandt (2008:10, tradução minha) observa que, na China, "o sistema médico geralmente não tem restrições legais ou éticas em usar corpos de pessoas executadas", e que desde 2004 "se acumulam evidências de que corpos de pessoas executadas vêm sendo utilizadas para a preparação de espécimes humanos plastinados". A autora cita dados obtidos no Instituto de von Hagens, em Dalian que apontaram haver apenas um corpo com doação documentada, enquanto a área de estoque continha 647 corpos intactos, 3.909 partes de corpos e 182 fetos, embrióes e neonatos, sendo que sete cadáveres mostravam sinais de execução, como ferimentos de bala na cabeça (Peuker \& Schulz ${ }^{11}$ apud Hildebrandt 2008:10). Von Hagens teria culpado Sui Hong-Jin, professor de anatomia da Universidade Médica de Dalian e seu gerente geral na época.

Com a queda das patentes de von Hagens em domínio público e a transferência de know-how que ele já havia feito através da parceria entre 
sua unidade de plastinação e a universidade médica local, Dalian transformou-se em um verdadeiro polo de produção de cadáveres plastinados, gerando corpos processados não só para von Hagens, mas também para seus concorrentes. $\mathrm{O}$ fornecedor da Premier Exhibitions era uma empresa sediada em Dalian, a Exhibition International LLC, que forneceu a ela, em 2004, corpos que foram dissecados e plastinados anos antes pela Universidade Médica de Dalian (Cuomo 2008), certamente frutos da parceria com von Hagens. De acordo com o compromisso assinado pela Premier Exhibition por exigência da Procuradoria Geral do Estado de Nova York (Cuomo 2008), não só inexiste prova documental de que a plastinação e a exibição pública dos corpos foram consentidas, como se descobriu que eram corpos não reclamados, "coletados pelo Departamento de Polícia chinesa e enviados à Universidade Médica de Dalian e outras universidades na China para educação e pesquisa" (Cuomo 2008:4; tradução minha).

Em 2005, a Dalian Medical University Plastination Co. Ltd. - empresa montada pelo ex-gerente de von Hagens, Sui Hong-Jin, com participação da Universidade Médica de Dalian - comprou a Exhibition International. No mesmo ano, a Universidade vendeu sua parte e a empresa foi reincorporada nas Ilhas Virgens Britânicas, conhecido paraíso fiscal, com o nome de Dalian Hoffen Bio Technique Company Limited. Um informativo do SEC ${ }^{12}$ (2006, tradução minha) cita Hong-Jin Sui como "o designer e fornecedor de todos os espécimes referidos" e mostra que sua empresa deveria fornecer, com exclusividade, por cinco anos pelo menos e ao custo de um milhão de dólares anuais, os "espécimes" explorados pela Premier Exhibitions nas suas exposições.

Sem a reserva da patente da plastinação, outras empresas passaram a competir com a Body Worlds, sendo a Premier Exhibition apenas uma das empresas que vêm replicando o rentável modelo de negócio de von Hagens. ${ }^{13}$ A audiência da Body Worlds (2009) já ultrapassou 28 milhões de visitantes e a da Premier Exhibition, 15 milhões de visitantes (Abas 2010). Contudo, os números superlativos das exposições podem tornar-se pequenos diante de outro negócio que é potencialmente mais lucrativo: o comércio em escala industrial de corpos e partes corporais plastinados.

A plastinação permitiu a inserção total do cadáver na lógica da commodity, tal qual aplicada ao gado ou ao petróleo, já que a tecnologia permite que se possa aproveitar o cadáver ao máximo, reduzindo-o a cortes e derivados que, depois de processados, serão vendidos como simples mercadorias pela Internet. A Dalian Hoffen Bio Technique Company possui toda uma linha de espécimes plastinados, animais e humanos, que pode ser comprada pela Internet $^{14}$ (figura 17). Recentemente, von Hagens também entrou no mercado on-line, vendendo todo tipo de "espécimes" plastinados e para todos os 
gostos: de bijuterias feitas de lâminas de pênis de cavalo por € 39,00 a corpos humanos dissecados e inteiros por cerca de 60 mil euros. Para quem quiser comprar corpos humanos em partes, o site oferece cabeças inteiras ou pela metade com preços que variam de $€ 8,6$ mil a $€ 18,5$ mil, torsos que vão de $€ 8,5$ mil a $€ 47$ mil, e órgãos e sistemas diversos por preços que oscilam entre $€ 550,00$ e $€$ 4,5 mil, dentre outros "produtos" (Gubener Plastinate GmbH 2010; Gubener Plastinate GmbH 2011).

Scheper-Hughes (2006:193, tradução minha) comenta o seguinte sobre o mercado de órgãos e tecidos humanos:

Mercados são, por natureza, indiscriminados e inclinados a reduzir tudo - incluindo seres humanos, seu trabalho e sua capacidade reprodutiva — ao estado de mercadorias (...) Em nenhum lugar isso é mais dramaticamente ilustrado do que nos atuais mercados de órgãos humanos e tecidos que suprem o mercado médico dirigido pela "oferta e demanda".

A lógica na qual o corpo é visto como um agregado de peças destacáveis e redutíveis ao estado de mercadoria - coisas que podem ser compradas, vendidas e roubadas - pode ser estendida ao mercado de corpos plastinados, já que este amplia o uso do corpo como matéria-prima e parece compartilhar dos mesmos mecanismos já estabelecidos no mercado negro de órgãos e tecidos.

Um agravante do mercado de corpos humanos plastinados é o de que, devido às características próprias desse processo, os produtos resultantes facilmente passam a ilusão de que são mercadorias de prateleira e que podem ser tratados como tais, não como restos humanos.

A ABC News (2008) exibiu em um programa uma guia de importação que acompanhava "espécimes" vindos da China para a Premier Exhibitions e na qual se vê que a mercadoria [commodity] é descrita no documento como "modelo plástico para treinamento médico" [Plastic model for medical teaching]. Confrontado com o documento, Arnie Geller, CEO da Premier Exhibitions na época, declarou que a informação estava correta, pois eles "são tecnicamente modelos plásticos". Esta afirmação ratifica a lógica por trás dessas exposições e dos sites de venda on-line especializados em lucrar com corpos humanos: afinal, já que parecem bonecos de plástico, por que não sentiriam a liberdade de tratá-los como bonecos? No mesmo programa, Todd Olson, presidente da Associação Americana de Anatomistas Clínicos, discorda que uma pessoa falecida, após passar por um "processo de conservação com plástico, seja desumanizada a ponto de tornar-se um modelo" que não é mais um ser humano. O médico é categórico: "me desculpe, é um ser humano". 
Figura 17. Página da versão chinesa do site da Dalian Hoffen Bio Technique Company

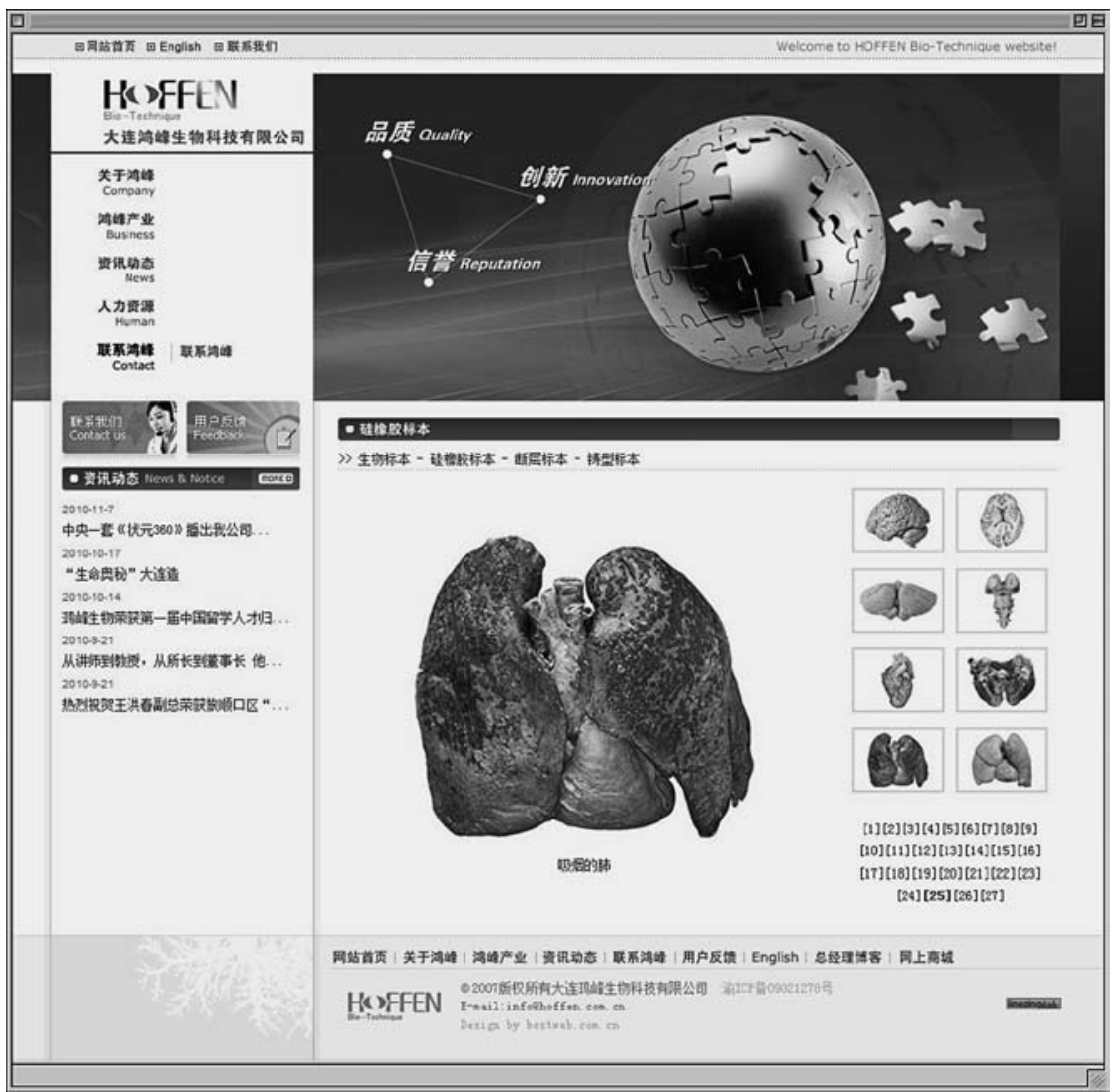

Recebido em 12 de outubro de 2011

Aprovado em 12 de setembro de 2012

Joon Ho Kim é doutorando do Departamento de Antropologia da Faculdade de Filosofia, Letras e Ciências Humanas da Universidade de São Paulo. E-mail: <jkim@usp.br > 


\section{Notas}

${ }^{1}$ Considera-se atualmente que o fígado é constituído de dois lobos anatômicos predominantes, o esquerdo e o direito, sendo que há na face visceral do fígado duas pequenas subestruturas ligadas ao lobo direito e chamadas também de lobos, o caudado e o quadrado (Cf. Findlen \& Bence 1999).

${ }^{2}$ O primeiro cânon do Quarto Concílio de Latrão, realizado em 1215, adverte que "a doença do corpo pode ser resultado do pecado", e o $22^{\circ}$ cânon ordena que "os médicos do corpo chamados ao leito do doente devem, antes de tudo, aconselhar que chamem o médico das almas, pois assim a saúde espiritual será restaurada e a saúde corporal se seguirá" (Twelfth Ecumenical Council 1937; tradução minha).

${ }^{3}$ Segundo a teoria humoral, o corpo é preenchido com quatro humores que correspondem aos quatro elementos básicos que compõem o universo e seus atributos: sangue, associado ao ar (quente e molhado); fleuma, associado à água (molhada e fria); bile negra, associada a terra (fria e seca); bile amarela, associada ao fogo (seco e frio).

${ }^{4}$ Os autores observam que o frontispício d'A estrutura do corpo humano não ilustra um anfiteatro real, mas uma estrutura provisória do mesmo tipo usada nos anfiteatros desmontáveis introduzidos em Pádua pelo professor de cirurgia e anatomia Alessandro Benedetti (1445-1525), e que "continuaram em uso até o ano acadêmico de 1583-1584, quando os cursos foram transferidos para as salas de aula internas da Universidade", onde "ainda existe um anfiteatro anatômico permanente, construído em 1594".

${ }^{5}$ As dissecações não ocorriam somente por interesse científico, "dissecava-se nas antecâmaras dos paços ou castelos cadáveres muitas vezes roubados" (Ariès 2012:194) e, como já observado, elas também eram uma forma de entretenimento das altas castas.

${ }^{6} \mathrm{O}$ desmembramento era normalmente obtido tracionando-se em direções opostas as pernas e os braços atracados a quatro cavalos.

\section{${ }^{7}$ R. H. Hunter 1931.}

${ }^{8}$ Katharine Park 2006.

${ }^{9}$ Um exemplo oposto é o que ocorreu com o doador masculino do Visible $\mathrm{Hu}$ man Project, cujo corpo foi cortado em 1.871 fatias e escaneado (National Library of Medicine 1996). Paradoxalmente, foi a destruição do corpo real que resultou na eternização de sua versão virtual, amplamente difundida pela Internet. Por algum motivo, a identidade de seu doador, Joseph Paul Jernigan, e as condições de sua morte, execução por injeção letal, vazaram. O anonimato é um direito que faz parte 
de todo "Termo de Consentimento Livre e Esclarecido", documento que estabelece os direitos e os deveres que devem regulamentar o uso ético de seres humanos nas pesquisas científicas. A violação deste direito básico possibilita que qualquer um rastreie as conexões sociais do "cadáver virtual" do Visible Human Project, tais como, por exemplo, sua ficha criminal e a rejeição de sua apelação, ambas disponíveis na Internet.

${ }^{10}$ Segundo as reportagens, o líquido pode ser sobra do polímero ou mesmo resto de gordura, ou ambos, resultante de um processo de plastinação deficiente.

${ }^{11}$ Torsten Peuker \& Christian Schulz 2004.

${ }^{12}$ Securities and Exchange Commission. Além de regular e fiscalizar o mercado financeiro, o SEC publica informações sobre as empresas que possuem ações na Bolsa de Valores, o que é o caso da Premier Exhibitions, cujas ações são negociadas na NASDAQ.

${ }^{13}$ Von Hagens denomina as exposições concorrentes de "imitações", alegação que desconsidera o fato de que boa parte dos cadáveres expostos por ele e todos os da Premier Exhibition compartilham da mesma origem - Dailan, provavelmente com o envolvimento das mesmas pessoas e facilidades locais - e que tanto ele quanto os demais afirmam manter ou terem mantido parceria com a Universidade Médica de Dailan.

${ }^{14} \mathrm{O}$ site em inglês (http://www.hoffen.com.cn/english/) é distinto do original em chinês (http://www.hoffen.com.cn/) e não apenas na aparência. Órgãos humanos plastinados são omitidos na versão em inglês.

\section{Referências bibliográficas}

ABAS, Márcia. 21/05/2010. "Corpos A exposição traz de volta ao Brasil cadáveres e órgãos humanos plastificados". O Globo. Disponível em: $<$ http://oglobo.globo.com/cultura/ mat/2010/05/19/corpos-exposicao-trazde-volta-ao-brasil-cadaveres-orgaoshumanos-plastificados-916634871. asp > . Acesso em: 25/10/2010.

ALLEN, James (ed.). 2000. Without sanctuary: lynching photography in America. Santa Fe: Twin Palms Publishers.
ARIÈS, Philippe. 2012. História da morte no Ocidente. Rio de Janeiro: Nova Fronteira.

ARQUIVO NACIONAL. 2007. "Anexo 4: Sentença proferida contra os Réus do Levante e Conjuração de Minas Geraes" In: Inconfidência em Minas: levante de Tiradentes. Brasília.

ASSOCIATED Press. 13/08/2005. "ATTORNEY general's decision may scuttle Tampa cadaver exhibit". USA Today. Disponível em: <http://www. 
usatoday.com/news/nation/2005-0813-cadaver-exhibit_x.htm $>$. Acesso em: 13/11/2010.

BARBOZA, David. 8/08/2006. "China turns out mummified bodies for displays". The New York Times. Disponível em: <http://www.nytimes. com/2006/08/08/business/world business/08bodies.html> Acesso em: 15/11/2010.

BARNUM, Alex. 27/05/2005. Oozing corpses raising eyebrows / Health department awaits results of tests on exhibition's bodies". SFGate.com. Disponível em: <http://articles.sfgate.com/2005-05-27/news/17374499_ 1_german-scientist-gunther-vonbodies-human-organs $>$. Acesso em: 15/11/2010.

BATTAGLIA, S.; MIGLIETTA, G. \& WENIGLYNDS, F. 2009. Heavenly medicine In: Museo Galileo. Web site. Disponível em: <http://brunelleschi.imss. fi.it/galileopalazzostrozzi/object/HeavenlyMedicine.html>. Acesso em: 15/08/2012.

BELTING, Hans. 2007. Antropología de la imagen. Buenos Aires: Katz Editores.

BENEDETTI, Winda. 28/09/2006. "Education or freak show? 'Bodies... The Exhibition' cashes in on our own curiosity". Seattlepi. Disponível em: <http://www.seattlepi.com/lifestyle/286689_bodies28.html>. Acesso em: $15 / 11 / 2010$.

BENTHAM, Jeremy. 1832. Extract from Bentham's will. London: University College London. Disponível em: $<$ http://www.ucl.ac.uk/BenthamProject/who/autoicon/will>. Acesso em: 04/08/2011.

BOBER, Harry. 1948. "The zodiacal miniature of the très riches heures of the Duke of Berry: Its sources and meaning". Journal of the War- burg and Courtauld Institutes, 11: 1-34. Disponível em: <http://www. jstor.org/stable/750460 > . Acesso em: 26/05/2012.

BODY WORLDS. 2009. "Body worlds anatomical exhibitions of donor bodies receives 28 millionth visitor" In: Press Releases \& Statements 2009. [Heidelberg]: Body Worlds. Disponível em: < http://www.bodyworlds. com/en/media/releases_statements/ releases_statements_2009.html>. Acesso em: 10/09/2012.

BRASLAUKAS, Ligia. 17/03/2001. “Médico esculpe em cadáveres reais e cria polêmica em Berlim". Folha On line. Disponível em: < http://www1. folha.uol.com.br/folha/ilustrada/ ult90u11660.shtml>. Acesso em: 28/10/2010.

CARREIRA, Eduardo José Antunes Netto (org.). 2000. Os escritos de Leonardo da Vinci sobre a arte e a pintura. Brasília: Editora Universidade de Brasília.

CAUCHON, Dennis \& MOORE, Martha. 02/09/2002. "Desperation forced a horrific decision". USA Today. Nation. Disponível em: < http://www.usatoday. com/news/sept11/2002-09-02-jumper_ x.htm >. Acesso em: 13/11/2010.

CBS. 5/02/2008. "Leaking fluids investigated at 'Bodies Revealed'". CBS Sacramento. Disponível em: < http:// cbs13.com/local/leaking.bodies.revealed.2.646100.html>. Acesso em: 15/11/2010.

CHOULANT, Ludwig. 1920. History and bibliography of anatomic illustration. Chicago: University of Chicago Press.

COLI, Jorge. 2003. "O sonho de Frankenstein". In: A. Novaes (org.), O homemmáquina: a ciência manipula o corpo. São Paulo: Editora Schwarcz. pp. 299-315. 
CORPO humano: Sinopse. 2007. São Paulo: Diverte Logística Cultural. Disponível em: < http://web.archive. org/web/20070220051204/www.exposicaocorpohumano.com.br/sinopse. html >. Acesso em: 15/11/2010.

CUOMO, Andrew M. 23/05/2008. Assurance of discontinuance. New York: Attorney General of the State of New York. Disponível em: <http://www. prxi.com/pdf/FEAOD.pdf $>$. Acesso em: 14/11/2010.

DEBORD, Guy. 2000. A sociedade do espetáculo. Rio de Janeiro: Contraponto.

DESCARTES, René. 1999. "Discurso do método". In: Descartes: vida e obra [Coleção Os pensadores]. São Paulo: Editora Nova Cultural. pp. 34-100.

DOUGLAS, Mary. 2003. Purity and danger. London: Routledge.

ELIAS, Norbert. 2001. "A solidão dos moribundos". In: A solidão dos moribundos: seguido de envelhecer e morrer. Rio de Janeiro: Jorge Zahar Ed. pp. 7-77.

FAUSTO, Carlos. 2002. "Banquete de gente: comensalidade e canibalismo na Amazônia". Mana. Estudos de Antropologia Social, 8(2):7-44.

FINDLEN, Paula \& BENCE, Rebecca. 1999. "A history of the liver, spleen and gallbladder". Early Science Lab. Stanford: Stanford University. Web site. Disponível em:http://www. stanford.edu/class/history13/earlysciencelab/body/liverpages/livergallbladderspleen.html> Acesso em: 21/06/2012.

FOUCAULT, Michel. 1999. Vigiar e punir: nascimento da prisão. Petrópolis: Editora Vozes.

GELlER, Judith B. (ed.). 2007. Corpo humano: real e fascinante. [s.l.]: Premier Exhibitions. Versão brasileira do catálogo da exposição.
GLOVER, Roy. 2007. "Introdução". In: J. B. Geller (ed.), Corpo humano: real e fascinante. [s.l.]: Premier Exhibitions. Versão brasileira do catálogo da exposição.

GUBENER Plastinate GmbH. 2010. Von Hagens products. Heideberg: Gubener Plastinate GmbH. Disponível em: < http://www.plastination-products.com/media/download/Kata_ Small_Kompl.pdf $>$. Acesso em: 04/08/2011.

. 2011. Price list. Heidelberg: Gubener Plastinate $\mathrm{GmbH}, 2011$. Disponível em: <http://www.plastination-products.com/media/download/ Preisliste_kompl.pdf $>$. Acesso em: 04/08/2011.

HALL, James. 2008. The sinister side: how left-right symbolism shaped western art. Oxford: Oxford University Press.

HAMBURG, Gail \& GOMEZ, Georgina. 21/05/2009. "Gunther Von Hagens' Body Worlds and Köperwelten not affiliated with Paris copycat display". Body Worlds: Press Releases \& Statements. Disponível em: <http://www. bodyworlds.com/en/media/releases_ statements/releases_statements_2009. html>. Acesso em: 13/11/2010. . 25/10/2010. "World premiere of Body Worlds vital to be unveiled at The Tech Museum". Body Worlds: Press Releases \& Statements. Disponível em: $<$ http://www.bodyworlds.com/en/media.html>. Acesso em: 15/11/2010.

HERTZ, Robert. 1990. "Contribución a un estudio sobre la representación colectiva de la muerte" In: La muerte y la mano derecha. Madrid: Alianza Editorial. pp. 13-102.

HILDEBRANDT, Sabine. 2008. "Capital punishment and anatomy: history and ethics of an ongoing association". Clinical Anatomy, 21(1):5-14. 
HOSKIM, Michael. 1999. The Cambridge concise history of astronomy. Cambridge: Cambridge University Press.

HUNTER, R. H. 1931. A short history of anatomy. London: John Bale Sons and Danielsson.

IMDb - The internet movie database. [s.d.]. Box office / business for Faces of Death. [Seattle?]: IMBd.com Inc. Disponível em: <http://www.imdb. com/title/tt0077533/business $>$. Acesso em: 13/11/2010.

INSTITUTE for plastination. 2007. Donating your body for plastination. Heidelberg: Disponível em: <http://www. bodymobil.de/Downloads/Englisch/BD_brochure_ENG_low_120208. pdf> Acesso em: 04/08/2011.

- [2007]. The Body Donation. Heidelberg: Institute for plastination. Disponível em: <http://www.koerperspende.de/en/body_donation/ the_body_donation.html> Acesso em: 10/11/2010.

KICKHÖFEL, Eduardo Henrique Peiruque. 2011a. "A ciência visual de Leonardo da Vinci: notas para uma interpretação de seus estudos anatômicos". Scientiae Studia, 9(2):319-355.

- 2011b. "A ordem do livro e outros textos (35 fólios em fac-símile da Coleção do Castelo de Windsor)". Scientiae Studia, 9(2):357-440.

KIEFER, Peter. 24/06/2010. "Anatomist Dr. Gunther von Hagens responds to report of collaboration with Lady Gaga". Body Worlds: Latest news. Disponível em: $<$ http://www.bodyworlds.com/en/media.html> . Acesso em: 04/08/2011.

KIM, Joon Ho. 2005. Imagens da cibercultura: as figurações do ciberespaço e do ciborgue no cinema. Dissertação de mestrado, Universidade de São Paulo. Disponível em: <http://pt.scribd.com/ doc/50786649/Joon-Ho-Kim-Ima-
gens-da-Cibercultura-As-figuracoesdo-ciborgue-e-do-ciberespaco-nocinema > . Acesso em: 29/05/2011.

KUHN, Thomas S. 1985. The copernican revolution. Cambridge: Harvard University Press.

LE BRETON, David. 2003. Adeus ao corpo. Campinas: Papirus.

-2011. Antropologia do corpo e modernidade. Petrópolis: Editora Vozes.

LEDER, Drew. 1990. The absent body. Chicago: University of Chicago Press.

LEITE BRANDÃO, Carlos Antônio. 2003. "O corpo do Renascimento". In: A. Novaes (org.), O homem-máquina: a ciência manipula o corpo. São Paulo: Editora Schwarcz. pp. 275-297.

NATIONAL Library of Medicine. 1996. Fact sheet: The Visible Human Project. Bethesda: U.S. National Library of Medicine. Disponível em < http://www.nlm. nih.gov/research/visible/visible_human. $\mathrm{html}>$. Acesso em: 04/08/2011.

NEW YORK STATE ATTORNEY GENERAL. 29/05/2008. Cuomo settlement with "bodies... the exhibition" ends the practice of using human remains of suspect origins. New York: New York State Attorney General. Disponível em < http://www.ag.ny.gov/media_ center/2008/may/may29a_08.html >. Acesso em: 04/08/2011.

O'MALLEY, Charles D. 1964. Andreas Vesalius of Brussels: 1514-1564. Berkeley and Los Angeles: University of California Press.

PARK, Katharine. 2006. Secrets of women: gender, generation, and the origins of human dissection. New York: Zone Books.

. 2009. "Myth 5: that the medieval church prohibited human dissection". In: Ronald L. Numbers (org.), Galileo goes to jail: and other myths about science and religion. Cambridge: Harvard University Press. pp. 43-49. 
PEUKER, Torsten \& SCHUlZ, Christian. 2004. Der über Leichen geht: Gunther von Hagens und seine 'Körperwelten'. Berlim: Christoph Links Verlag.

RICHARDSON, Ruth. 2000. Death, dissection and the destitute. Chicago: Chicago University Press.

ROZA, Greg. 2011. The eighth amendment: preventing cruel and unusual punishment. New York: Rose Publishing Group.

SAUNDERS, J. B. de C. M. \& O'MALLEY, Charles. 2003. Andreas Vesalius de Bruxelas. Cotia: Ateliê Editorial.

SEC. 2006. SEC Info: Premier Exhibition Inc. Washington: Securities and Exchange Commission. Disponível em $<$ http://www.secinfo.com/dsvr4.v71s. d.htm > . Acesso em: 31/10/2010.

SCHEPER-HUGES, Nancy. 2006. “The global traffic in human organs: A Report presented to the house subcommittee on international operations and human rights, United States Congress on june 27, 2001". In: A. Howard \& R. Borofsky, Public Anthropology. Disponível em: < http://www.publicanthropology. org/TimesPast/Scheper-Hughes.htm>. Acesso em: 24/10/2010.

SCHETER, Anna. 26/02/2008. "Body Donors Pick Their Poses for Plastination Exhibit". ABC News. Disponível em: $<$ http://abcnews.go.com/Blotter/ story? $i d=4345007 \&$ page $=1>$. Acesso em: 15/11/2010.

SCHWARTZ, Vanessa. 2001. "O espectador cinematográfico antes do aparato do cinema: o gosto do público pela realidade na Paris fim de século". In: L. Charney \& V. Schwartz (orgs.), O cinema e a invenção da vida moderna. São Paulo: Cosac \& Naif. pp. 441-440.

SIMMEL, Georg. 1967. "A metrópole e a vida mental". In: O. Velho (org.), O fenômeno urbano. Rio de Janeiro: Zahar. pp. 13-28.
SIMON, Jonathan. 2002. The theater of anatomy: the anatomical preparations of Honoré Fragonard. EighteenthCentury Studies, 36(1):63-79. Disponível em: < http://www.jstor.org/stable/ 30053339 > . Acesso em: 3/9/2012.

SINGER, Ben. 2001. "Modernidade, hiperestímulo e o início do sensacionalismo popular". In: L. Charney \& V. Schwartz (orgs.), O cinema e a invenção da vida moderna. São Paulo: Cosac \& Naif. pp. 115-148.

SIRAISI, Nancy G. 1994. "Vesalius and Human Diversity in De humani corporis fabrica". Journal of the Warburg and Courtauld Institutes, 57:60-88. Disponível em: <http://www.jstor. org/stable/751464>. Acesso em: 17/05/2012.

SMITH, T. Southwood. 1827. Use of dead to the living. Albany: Websters and Skinners. Disponível em: <http://www.archive.org/download/ useofdeadtolivin00smit/useofdeadtolivin00smit.pdf $>$ Acesso em: 23/10/2010.

TWELFTH ECUMENICAL COUNCIL. The Canons of the Fourth Lateran Council, 1215. SCHROEDER, H. J. (ed.). 1937. Disciplinary decrees of the general councils: Text, translation and commentary. St. Louis: B. Herder. pp. 236-296. Disponível em < http://www. fordham.edu/halsall/basis/lateran4. asp>. Acesso em: 15/08/2012.

ULABY, Neda. 11/08/2006. "Origins of Exhibited Cadavers Questioned". NPR. Disponível em: < http:// www.npr.org/templates/story/story. php? storyId $=5637687>$. Acesso em: 25/10/2010.

UNIVERSITY COLLEGE LONDON. 2010. "Auto-Icon". UCL Bentham Project. Disponível em: <http://www.ucl. ac.uk/Bentham-Project/who/autoicon >. Acesso em: 23/10/2010. 
VESALIUS, Andreas. 2003. On the fabric of the human body: An annotated translation of the 1543 and 1555 editions of Andreas Vesalius' De Humani Corporis Fabrica. Evanston: Northwestern University. Disponível em: <http://vesalius.northwestern. edu/>. Acesso em: 17/08/2012.

VILAÇA, Aparecida. 1992. Comendo como gente: formas do canibalismo Wari'. Rio de Janeiro: Editora UFRJ.

VON HAGENS, Gunther. [s.d.]. Anatomy and plastination. [s.l.]: [s.n.]. Disponível em: <http://www.koerperwelten. com/Downloads/AnatomyandPlastination.pdf $>$. Acesso em: 13/11/2010. · 14/03/2003. "Gunther von Hagens' statement about the ARD program 'Dances with corpses' on 12 March 2003", 11.30 pm. Heidelberg: Institut für Plastination. Disponível em: $<$ www.bodyworlds.com/Downloads/ stellungnahmeard_en.pdf $>$. Acesso em: 12/11/2010.

WALTER, Tony. 2004. "Plastination for display: a new way to dispose of the dead". The Journal of the Royal Anthropological Institute, 10(3):603-627.

WIENER, Norbert. 1948. Cybernetics: or the control and communication in the animal and the machine. New York: The Technology Press.

\section{Imagens}

Figura 1: LINDSEY, Mike. The kicker: Gunther von Hagens' Body Worlds 2, Museum of Science, Boston. 2006. Uma fotografia. Disponível em: <http://www.flickr.com/photos/ dosmosis/241958768/>. Acesso em: 10/09/2012. Alguns direitos reservados (CC BY-NC-ND 2.0).

Figura 2: STEVEnSON, Paul. Body Worlds anatomy exibition, London.
2004. Uma fotografia. Disponível em: <http://commons.wikimedia. org/wiki/File:Koerperwelten01.jpg >. Acesso em: 10/09/2012.

Figura 3: MOONEY, Paty. A plastinated human body exhibited at the Body Worlds show, Museum of Natural History, San Diego. 2009. Uma fotografia. Disponível em: < http://en.wikipedia. org/wiki/File:Plastinated_Human_ Body_Worlds_San_Diego.jpg > . Acesso em: 10/09/2012.

Figura 4: JEBULON. Ecorché (momifié) d'un cheval et de son cavalier, (détail), réalisé entre 1766 et 1771 par l'anatomiste français Honoré Fragonard (1732-1799). Musée Fragonard de l'Ecole Nationale Vétérinaire d'Alfort, Maisons-Alfort, Val-de-Marne, France. 2011. Uma fotografia. Disponível em: <http://commons.wikimedia.org/wiki/ File\%3A\%C3\%89corch\%C3\%A9_cavalier_Fragonard_Alfort_1.jpg $>$. Acesso em: 10/09/2012.

Figura 5: LIMBOURG, Pol; LIMBOURG, Jean \& LIMBOURG, Hermann. Très Riches Heures du Duke of Berry: L'Homme zodiacal. [1411-1416?]. Pintura em têmpera sobre tela, $29 \mathrm{~cm}$ x $21 \mathrm{~cm}$. Coleção do Museu Condé [Ms.65, f.14v]. Disponível em: <http://fr.wikipedia. org/wiki/Fichier:Anatomical_Man. jpg >. Acesso em 10/09/2012.

Figura 6. Imagem de homem zodíaco In: KETHAM, Johannes de. 1494. Fasciculo de medicina. Venice: Zuane \& Gregorio di Gregorii. Disponível em: < http://archive.nlm.nih.gov/proj/ ttp/kethamgallery.htm $>$. Acesso em: 04/08/2011.

Figura 7. Da Vinci, Leonardo. 1489. [RL 19058v] A skull sectioned. Pena e nanquim sépia, $19 \mathrm{~cm}$ x 13,7 cm. Royal Collection. Disponível em: <http:// www.royalcollection.org.uk/microsites/ leonardo/> . Acesso em 10/09/2012. 
Figura 8. Da Vinci, Leonardo. 1510-11. [RL 19005r] The muscles of the arm, and the veins of the arm and trunk. Pena e tinta sobre carvão, 28,9 x 19,9 cm. Royal Collection. Disponível em: $<$ http://www.royalcollection.org.uk/ exhibitions/leonardo-da-vinci-anatomist/>. Acesso em 10/09/2012.

Figura 9. Ilustração anatômica. In: FRIES, Lorenz. Spiegel der Artzny. 1517. Strasburg. Disponível em: <http:// daten.digitale-sammlungen.de/0002/ bsb00025948/images/index.html> . Acesso em: 16/08/2012.

Figura 10. Ilustração anatômica. In: BERENGARIO DA CARPI, Jacopo. 1523. Isagogae breues, perlucidae ac uberrimae, in anatomiam humani corporis a communi medicorum academia usitatam. Bologna: Beneditcus Hector. Disponível em: < http://www. nlm.nih.gov/exhibition/historicalanatomies/berengario_home.html>. Acesso em: 16/08/2012.

Figura 11. Ilustração anatômica. In: DRYANDER, Johann Eichmann. 1536. Anatomia capitis humani. Marburg: E. Cervicorni. Disponível em: <http://web2.bium. univ-paris5.fr/img/?annee $=1536>$. Acesso em: 10/09/2012.

Figura 12. Ilustração anatômica. In: VESAliUs, Andreas. 1543. De humani corporis fabrica. Basileae: Ex officina Joannis Oporini. Disponível em: < http://archive.nlm.nih.gov/proj/ ttp/vesaliusgallery.htm > . Acesso em: 04/08/2011.

Figura 13: Ilustração anatômica. In: VESALIUS, Andreas. 2003. On the fabric of the human body: An annotated translation of the 1543 and 1555 editions of Andreas Vesalius' De Humani Corporis Fabrica. Evanston: Northwestern University. Disponível em: < http://vesalius.northwestern. edu/> . Acesso em: 17/08/2012.
Figura 14. Ilustração anatômica. In: VALVERDE DE AMUSCO, Juan. 1560. Anatomia del corpo humano. Roma: Per Ant. Salamanca, et Antonio Lafreri. Disponível em: < http://www.nlm. nih.gov/exhibition/historicalanatomies/valverde_home.html>. Acesso em: 04/08/2011.

Figura 15. Ilustração anatômica. In: BIDLOO, Govard. 1685. Anatomia humani corporis. Amsterdam: Someren, Dyk \& Boom. Disponível em: < http://digi.ub.uni-heidelberg. de/diglit/bidloo1685 > . Acesso em: 10/09/2011.

Figura 16. Ilustração anatômica. In: ALBINUS, Bernhard Siegfried. 1749. Tabulae sceleti et musculorum corporis humani. Londini: Typis H. Woodfall, impensis Johannis et Pauli Knapton. Disponível em: <http://www.nlm. nih.gov/exhibition/historicalanatomies/albinus_home.html $>$. Acesso em: 04/08/2011.

Figura 17. Dalian Hoffen Bio Technique Company. Web site. Disponível em: $<$ http://www.hoffen.com.cn/>. Acesso em: nov. 2010.

\section{Filmes e vídeos}

20/20. Inside the Bodies Exhibit. New York: ABC News, 15 fev. 2008. Disponível em: <http://abcnews.go.com/ video/playerIndex $? \mathrm{id}=4300207>$. Acesso em: 15/11/2010.

9/11: The Falling Man. 2006. Direção: Henry Singer. Produção: Sue Bourne. London, Darlow Smithson Productions. Vídeo.

Faces of Death. 1978. Direção: John Alan Schwartz. Produção: William B. James. [s.l.]. F.O.D. Productions. Filme. 


\section{Resumo}

"Espécimes" inodoros, secos e quase eternos, produzidos a partir de cadáveres humanos por uma técnica chamada plastinação, estão sendo amplamente usados como modelos de anatomia em exposições e faculdades de medicina. Milhões de leigos já viram corpos dissecados em uma das espetaculares exposições de anatomia pelo mundo e um novo mercado on-line de "espécimes" humanos plastinados está crescendo. Mais do que transformações físico-químicas, a plastinação, associada a outros procedimentos, também realiza uma transformação simbólica que reduz o corpo-pessoa a corpo-objeto para neutralizar a poluição e o tabu associados aos cadáveres humanos. Contudo, as circunstâncias obscuras sobre como esses corpos foram doados, comprados ou mesmo roubados traz o status de pessoa de volta aos corpos, assim como chama a nossa atenção para novas questões éticas e morais.

Palavras-chave Corpo, Plastinação, Cadáver, Entretenimento, Espetáculo.

\section{Abstract}

Odorless, dry and almost everlasting "specimens", produced from human corpses by a technique called plastination, are being used as anatomy models in exhibitions and medical schools. Millions of lay people have already seen dissected corpses in one of the spectacular human anatomy exhibitions around the world and a new on-line market for plastinated human "specimens" is growing. More than chemical and physical transformations, plastination, associated with other procedures, also makes a symbolic transformation that reduces the person-body into object-body in order to neutralize the pollution and the taboo associated with human corpses. But unclear circumstances about these bodies and questions as to whether they have been donated, sold, or even stolen bring status as "people" back to the corpses and draws our attention to new ethical and moral questions.

Key words Body, Plastination, Corpse, Entertainment, Spectacle. 